\title{
T.C. Kamu Denetçiliği Kurumu ile Türkiye İnsan Hakları ve Eşitlik Kurumu'nun Kurumsal Yapı, İşleyiş ve Etkinlikleri Açısından Bir Karşılaştırma
}

\author{
A Comparison of the Ombudsman and Turkey Human Rights and Equality \\ Institution in Terms of Institutional Structure, Functioning and Efficiency
}

\author{
Doktora Öğrencisi Ayça BEYOĞLU (D) 1
}

\begin{abstract}
$\ddot{\mathbf{O} z}$
Hukuk devleti ilkesi, devletin güçlü otoritesi karşısında bireyleri koruyan temel unsur olarak karşımıza çıkmaktadır. Günümüzde karmaşıklaşan toplumsal koşullar karşısında insan hak ve özgürlüklerinin korunup geliştirilmesi ve ihlallerin önlenebilmesi konusunda yeni mekanizmalara ihtiyaç doğmaktadır. Uluslararası koruma araçlarının oynadığı hayati role karşın, insan haklarının etkin bir şekilde korunması ulusal düzeyde başlamaktadır. Birleşmiş Milletler Genel Kurulu tarafından kabul edilen "Paris Prensipleri" insan haklarının ulusal düzeyde korunup geliştirilmesi için kurulacak kurumların statüsü ve verimli şekilde çalışabilmeleri için sahip olmaları gereken temel standartları belirlemiştir. Bu çalışmada, Türkiye'de insan hakları alanında ulusal koruma mekanizmaları olarak çalışmak üzere oluşturulan T.C. Kamu Denetçiliği Kurumu ile Türkiye İnsan Hakları ve Eşitlik Kurumu ele alınmaktadır. Bu iki kurum, öncelikle tarihsel olarak ulusal mevzuatımıza girme süreci kapsamında ele alınmıştır. İzleyen bölümlerde ise kurumsal yapı, işleyiş ve etkinlikleri açısından Paris İlkeleri kapsamında karşılaştırılmış ve idare ile bireyler arasındaki ilişkilere ilişkin olarak vermiş oldukları kararların etkinliği değerlendirilmiştir. Sonuç bölümünde ise her iki kurumun insan haklarını koruma ve geliştirme yönünden etkinliği tartışılarak eleştiri ve önerilere yer verilmiştir. Literatürde, Türkiye örneğine ait olan bu iki kurum genellikle tekil olarak ele alınmakta ve özellikle kurumsal yapı, işleyiş ve etkinlikleri açısından karşılaştırma yapan çalışmaların çok sınırlı bir alana sahip olduğu görülmektedir. Bu sebeple karşılaştırma yönteminin tercih edilmesi çalışmaya ayrı bir önem atfetmektedir.
\end{abstract}

Anahtar Kelimeler: İnsan hakları, ulusal koruma, Paris Prensipleri, ombudsman, Türkiye İnsan Hakları ve Eşitlik Kurumu

Makale Türü: Araştırma

\begin{abstract}
The principle of the rule of law, emerges as the basic element that protects individuals against the strong authority of the state. In the face of today's complex social conditions, new mechanisms are also needed to protect and improve human rights and freedoms to prevent violations. Even though the vital role played by international protection instruments, effective protection of human rights begins at national level. The Paris Principles, adopted by The United Nations General Assembly, determined the status of national institutions to be established to protect and improve human rights and the standards requred for their most efficient work at national level. In this study, Ombudsman and Turkey Human Rights and Equality Institution that created in the field of human rights protection national mechanisms in Turkey are discussed. First, these two institutions have historicaly been handled within the scope of their entry into our national legislation. In the following chapters, the institutional structure, functions and efficiency are compared within the scope of Paris Principles and the effectiveness of their decisions regarding the relations between the administration and individuals has been evaluated. In the conclusion part, the effectiveness of both institutions in terms of protecting and improving human rights was discussed and
\end{abstract}

\footnotetext{
${ }^{1}$ Trakya Üniversitesi Sosyal Bilimler Enstitüsü, Kamu Yönetimi Doktora Programı, ayca.beyoglu@hotmail.com

Atıf için (to cite): Beyoğlu, A. (2021). T.C. Kamu Denetçiliği Kurumu ile Türkiye İnsan Hakları ve Eşitlik Kurumu'nun kurumsal yapı, işleyiş ve etkinlikleri açısından bir karşılaştırma. Afyon Kocatepe Üniversitesi Sosyal Bilimler Dergisi, 23(3), $992-1013$.
} 
criticism and suggestions were included. In the literature, these two institutions that an exampe of Turkey are generaly considered singular. It is seen that studies that make comparisons especially in terms of institutional structure, functioning and efficiency have a very limited scope. For this reason, choosing the comparison method attaches a special importance to the study.

Keywords: Human rights, national protection, The Paris Principles, ombudsman, Turkey Human Rights and Equality Institution

Paper Type: Research

\section{Giriş}

İnsan hakları, kişinin sırf insan olduğu gerekçesiyle sahip olduğu haklar olarak, bu haklara dayanan taleplerde de bulunabilmeye yetkili olmak demektir (Donnelly, 1989, s 19).

Bu hak ve yetki dâhilinde insan hakları, ulusal ve uluslararası düzey olmak üzere iki farklı düzlemde ele alınmakta ve korunmaktadır. Bu kapsamda ulusal düzey, devletin hem koruyucu olarak üstlendiği rol hem de bazı durumlarda ihlallerin doğrudan kaynağı olabilmesi sebebiyle mağdurların ihlaller ile karşılaştığı ilk yüz olmaktadır.

Uluslararası düzeydeki koruma ve geliştirme çabaları ise uluslararası kuruluşlar eli ile gerçekleşmektedir. Bu kapsamda, Birleşmiş Milletler, insan haklarının korunup geliştirilmesi sürecinin temel aktörüdür. Etkin korumanın ulusal ve uluslararası mekanizmaların uyumunun ne derece sağlanabildiği ile iliş̧kili olduğu ortadadır. Ulusal insan hakları kurumları, yargı gibi doğrudan bir devlet gücü ya da sivil toplum gibi tamamen devlet dışı bir yapılanma olmanın ötesinde insan hakları ihlallerine karşı mağdurları koruyan tarafsız bir mekanizma işlevi görmelidir.

Ulusal kurumların görevlerini etkin ve verimli bir şekilde yerine getirebilmeleri sahip oldukları yetki alanının genişliği, ulusal mevzuatta nerede konumlandırıldıkları, oluşum statüleri, verdikleri kararların niteliği ve bağımsızlıkları ile yakından ilişkilidir. Bu kapsamda, yapı ve işleyiş açısından nitelikleri ülkeden ülkeye farklılık gösterebilen ulusal kurumların sahip olması gereken temel niteliklere ilişkin düzenleme ise 20.12.1993 tarihli 48/134 sayılı BM Genel Kurul kararı ile temeli atılan Paris Prensipleri'dir. Paris Prensipleri, bağlayıcı niteliği olmayan, ancak dünya genelinde bağlayıcıymış gibi kabul edilerek riayet edilmesi gerekli görülen ilkelerdir.

$\mathrm{Bu}$ çalışmada, ülkemizde insan haklarının ulusal düzeyde korunup geliştirilmesi alanında görev yapan kurumlar olan T.C. Kamu Denetçiliği Kurumu ile Türkiye İnsan Hakları ve Eşitlik Kurumu incelenmektedir. Kamu Denetçiliği Kurumu, kamu idareleri ve mağdur bireyler arasında arabulucu görevi üstlenerek, yargılama ve çeşitli hak arama yolları dışında kalan alternatif bir denetim mekanizması niteliği taşımaktadır. Türkiye İnsan Hakları ve Eşitlik Kurumu ise, insan haklarının korunup geliştirilmesi, ayrımcılık ile mücadele etme ve ulusal önleme mekanizması görevini üstlenmek üzere kurulmuştur. Çalışmada, bu iki kurum, literatürde genel olarak incelendiği şekli ile tekil olarak ele alan çalışmaların aksine karşılaştırma kapsamında kurumsal yapı, işleyiş ve etkinlikleri açısından ele alınarak; sahip oldukları görev, yetki ve sorumluluklar, oluşum yapıları ve işleyişleri ile insan haklarının korunup geliştirilmesi anlamındaki etkinlikleri Paris Prensipleri kapsamında incelenmekte ve bu mekanizmaların eksikliklerine yönelik eleştirilere yer verilerek iyileştirilebilecek noktalar üzerinde durulmaktadır. Bu kapsamda, makalenin temel amacı: Türkiye'de işlevsel bir ulusal insan hakları koruma ve geliştirme mekanizmasının varlığından bahsetmek mümkün müdür? sorusundan yola çıkarak T.C. Kamu Denetçiliği Kurumu ile Türkiye İnsan Hakları ve Eşitlik Kurumu'nun Paris Prensipleri ile belirlenen ve ulusal insan hakları kurumlarının sahip olmas1 gereken temel değer ve nitelikleri ne derece karşıladığını inceleyerek ülkemizdeki mevcut duruma bir ayna tutmaktır. 
Çalışmada öncelikle Paris Prensipleri incelenmiş ve ulusal insan hakları kurumlarının taşıması gereken temel nitelikler belirlenmiştir. Ülkemiz örneği olarak ele aldığımız iki kurumun ulusal mevzuatımıza giriş sürecini belirleyebilmek için tarihsel süreç ele alınmış, ilgili mevzuat hükümleri incelenmiştir. Temel yasal düzenlemeler olarak, 6328 sayılı Kamu Denetçiliği Kurumu Kanunu ve 6701 sayılı Türkiye İnsan Hakları ve Eşitlik Kurumu Kanunu incelenmiş ve Paris Prensipleri ile karşılaştırılmasına dayanan bir yöntem izlenmiş̧tir. Konu ve kurumlar ile ilgili olarak detaylı bilgiye erişebilmek için ise kitaplar, makaleler, internet kaynakları ve gazete haberlerinden faydalanılmıştır. Kurumların faaliyet ve kararlarına ilişkin bilgilere resmi internet sitelerinde yer alan faaliyet raporlanı ve yıllık raporlar yolu ile erişilmiştir.

\section{1. Ülkemizde Ulusal Koruma Mekanizmalarının Gelişim Süreci}

İnsan haklarının korunup geliştirilmesine yönelik uluslararası çabaların temeli, 20. yüzyılın başından ortasına dek süren iki adet dünya savaşının yıkıcı sonuçları sebebiyle, sadece insan olma onurunun dünya gündemine taşınmasına dayanmaktadır. Bu kapsamda sağlanan uluslararası iş birliği Birleşmiş Milletlerin (BM) kurulması ile sonuçlanmıştır. İnsan haklarının ulusal düzeyde korunup geliştirilmesine yönelik olarak kurulması gereken ulusal kurumların statüsüne ilişkin ilk uluslararası çalıştay ise 1991 yılında Paris’te gerçekleştirilmiştir. Temeli bu çalıştay ile atılan Paris Prensipleri, BM İnsan Hakları Komisyonunca 1992/54 sayılı karar ile kabul edilmiş ve Paris Prensipleri 20 Aralık 1993 tarih ve 48/134 sayılı karar ile BM Genel Kurulu'nca kabul etmiştir (tihek.gov.tr).

Paris Prensiplerine göre, ulusal koruma mekanizmaları olarak oluşturulan ve bu rolü sebebiyle insan haklarının korunup geliştirilmesi ile ilgili konulara ilişkin görüş bildirme, tavsiyelerde bulunma ve öneri-raporlar sunma görev ve sorumluluğu olan ulusal insan hakları kurumlarının sahip olması gereken temel nitelikler bulunmaktadır.

$\mathrm{Bu}$ kapsamda ulusal koruma mekanizmalarının en temel güvencesi anayasal bir statüde oluşturulmalarıdır. Anayasal statü dışında bir koruma, kurumları dışarıdan gelecek keyfi müdahalelere açık hale getirecek ve işlerliğini olumsuz yönde etkileyecektir. Anayasal statüyü destekleyen bir husus da kurumlara tanınan yetkilerin olabildiğince açık şekilde belirlenmiş ve yasal temelde de bu şekilde düzenlenmiş olmasıdır. Bu yetkilerin uygun görülen insan hakları ihlal vakalarına el koyabilmek de dâhil olmak üzere geniş tutulması önemlidir. Bağımsızlıkları temelinde, üye oluşumu ve üyelerin çalışma şartlarının nasıl sağlandığg gibi yeterli ekonomik kaynak ve teknik alt yapılar temelinde sahip olacakları donanımlar da kurumları işlevsel kılacak temel noktalardır (Paris Prensipleri).

Paris Prensipleri, ulusal kurumların sahip olması gereken niteliklere ilişkin temel çerçeveyi çizmekle birlikte belirli bir ulusal insan hakları kurumu yapılanması ve modellemesi önerisinde bulunmamakta ve bununla birlikte "Viyana Deklarasyonu ve Eylem Programi" da her ülkenin kendi yapısına uygun olan yapılanmayı seçme hakkına sahip olduğunu düzenlemektedir. Bu çerçevede, ülkeden ülkeye farklılaşan tercihlere bakıldı̆̆ında, ulusal insan hakları kurumlarının "komisyon", "ombudsman", "danışma komitesi", "enstitü modeli" ve "hibrid modeli" şeklinde yapılandırıldıkları görülmektedir (Didinmez, 2020, s. 12).

Çağdaş devlet anlayışının koruyucu ilkeleri olarak "hukuk devleti" ve "demokratik devlet" ilkeleri vatandaşların temel hak ve özgürlüklerinin tanınması ve korunmasının temel güvence kaynaklarıdır. Bu güvencenin bir diğer koruma kalkanı ise idarenin de hukukla bağlı olması; vatandaşlar karşısında eylem ve işlemleri sebebiyle yarg1 denetimine tabi tutulabilmesidir (Kahraman, 2011, s. 356).

$\mathrm{Bu}$ anlayış kapsamında, her ülke, ulusal denetim modelleri arayışında hem kendi tarihsel-kurumsal deneyimlerinden hem de diğer ülkelerin başarılı olduğu deneyimlenmiş denetim modellerinden faydalanmaktadır. Ülkemizde açısından incelendiğinde, idarenin 
denetimi: "siyasi denetim", "idari denetim" ve "yargısal denetim" gibi farkl1 yollardan yapılmaktadır (Gözler, 2017, s. 216).

İhlaller karşısında idarenin denetlenmesi konusunda "ombudsman denetimi" dünyada en sık kullanılan denetim yolu olarak karşımıza çıkmaktadır. Köken itibariyle İsveç çıkışı olan kavram, "temsilci", "kişi”" olarak, haksızlıklara karşı koruma ve temsil işlevlerini üstlenmektedir (Oxfordlearnersdictionaries).

Kurum ve işlev olarak dünya uygulamaları incelendiğinde, kurumun ana hedefinin yönetimin iyileştirilmesi olduğu söylenebilir; insan haklarının korunmasının yanı sıra bireyin uğradığını savunduğu haksızlıklar karşısında hesap sorabilmesi temel kaygı ve uğraş alanıdır. Uygulanan yargisal, idari, siyasi denetim yollarının yanı sıra basın ve kamuoyunun tepkisi de işlevsel olmakla birlikte ombudsman denetimi de işletilmesi gereken bir denetim yolu olmalıdır (Fendoğlu, 2010, s. 4).

Ombudsmanlık denetiminin uygulandığı ülkelerde kurumun oluşum ve işleyişi değerlendirildiğinde uzlaşılan temel özellikler aşağıdaki gibi sıralanabilir (Büyükavcı, 2008, s. 12):

- Ombudsman siyasi yönü itibariyle tarafsızdır.

- Bağımsız karar alma yetkisine haiz olmalıdır.

- Görevlerini etkin bir şekilde yerine getirebilmesine olanak sağlayacak standartlarla donatılmalıdır.

- Ombudsman, ele aldığı başvuruları tek tek değerlendirmelidir.

- Ombudsmana, erişilebilirlik yolları açık ve çeşitli olmalıdır.

- Kamuoyu ile ilişsisi işlevsel düzeyde olmalıdır.

Dünya uygulamaları gözlemlendiğinde, ombudsmanlık kurumuna olan ilginin değişen toplumsal, siyasal ve ekonomik koşullar ve talepler ile birlikte arttı̆̆ görülmektedir. $\mathrm{Bu}$ kapsamda farklı tür-yapılarda olan ve alanında uzmanlaşmış ombudsmanlık uygulamalarına rastlanmaktadır. Alanında uzman kişi ve işlevsel kurumların gerekliliğine olan inanç (Oytan, 1975, s. 193-194) ve beraberinde ombudsmanlık kurumunun başarılı uygulamaları ile adeta bir branşlaşma yaşanmış ve idarenin tüm eylem ve işlemlerinden kaynaklanan sorunlar ile muhatap olan genel amaçlı-yetkili ombudsmanların yanı sıra özel amaçlı (askeri, parlamento, eğitim, sağlık, kadın-çocuk hakları, engelliler, yerel yönetimler, basın-medya vb.) ombudsmanlık uygulamaları ve ulus üstü düzeyde Avrupa Ombudsmanlığ 1 gibi yapılanmalar da oluşturulmuştur. (Efe ve Demirci, 2013, s. 49-73).

Ülkemizde ombudsmanlık kurumuna duyulan ihtiyaç ve yapılanma izlendiğinde ise ombudsmanlığın oluşturulması fikri bazen tartışma boyutunda kalmış bazen de yasal çalışmalar düzeyinde gündeme gelmiştir. Kamu Denetçiliği Kurumu'nun (KDK) oluşturulması ile sonuçlanan tarihsel ve yasal süreçte ombudsmanlık kurumunun fonksiyonlarını kısmi düzeyde de olsa yerine getirebilen bazı düzenleme ve yapılanmalar oluşturulmuştur (Kahraman, 2011, s. 366).

$\mathrm{Bu}$ mekanizmaları ombudsmanlık kurumu ile nitelik ve işlevleri itibariyle karşılaştırdığımızda:

Ele alabileceğimiz ilk yapılanma olarak Devlet Denetleme Kurulu incelendiğinde, anayasal statüde bir yapılanma tercih edildiği görülmektedir. Anayasamızın 108. maddesi, "idarenin hukuka uygunluğunun, düzenli ve verimli şekilde yürütülmesinin ve geliştirilmesinin sağlanması amacıyla, işleyiş̧i, üyelerinin görev süresi ve diğer özlük işleri bakımından Cumhurbaşkanlığına bağll" Devlet Denetleme Kurulu'nun kurulmasını öngörmüştür (Madde(md/108). Madde incelendiğinde ilk dikkati çeken husus, kurulun bağımsız olmayışı ve 
Cumhurbaşkanı ile ilişkilendirilmiş olmasıdır. Bununla birlikte kurul, idare üzerinde denetim uygulayabilen bir mekanizma oluşturması suretiyle ombudsmanlık mekanizması ile benzerlik göstermektedir. Anayasal düzenlemede 108/1.madde, kurulu, harekete geçebilmesi noktasında da "Cumhurbaşkanının istemde bulunması" şartı ile bağlı kılmıştır. Benzer şekilde kurul, yaptığı inceleme, araştırma ve denetlemeleri ile ilgili tespitlerini de Cumhurbaşkanına bildirmekle yükümlüdür. $\mathrm{Bu}$ sebeple ele aldığ 1 olumsuzlukların çözümünde işlevsel bir rolü bulunmamaktadir.

Ombudsmanlık mekanizması ile karşılaştırabileceğimiz bir diğer düzenleme olarak "dilekçe hakk1", anayasanın 74. maddesinde "Dilekçe, bilgi edinme ve kamu denetçisine başvurma hakkl" olarak düzenlenmiştir. Dilekçe hakkından faydalanabilecek olan kişiler; vatandaşlar ve karşılıklılık esası gözetilmek kaydıyla Türkiye'de ikamet eden yabancılar olarak düzenlenmiştir. Bu hakkı kullanarak, idare ile ilgili dilek ve şikâyetleri, "yazılı bir şekilde" ilgili kurum veya kuruluşa ve moral değeri olarak daha yüksek bir işlevselliği olduğunu söyleyebileceğimiz Türkiye Büyük Millet Meclisi'ne (TBMM) iletebilmektedirler. Bu yol kullanılarak iletilen talep ve şikâyetler, meclisin kendi üyelerinden oluşan bir komisyon aracılığıyla incelenmekte, ancak komisyonun aldığı kararların "bağlayıcı" bir niteliği bulunmamaktadır (TBMM Dilekçe Komisyonu).

TBMM düzeyinde oluşturulan bir diğer hak arama mekanizması ise "TBMM İnsan Haklarını İnceleme Komisyonu"'dur. 1990 tarih ve 3686 sayılı İnsan Haklarını İnceleme Komisyonu Kanunu, komisyonun inceleme alanına ilişkin kapsamı; "T.C. Anayasası ile Insan Hakları Evrensel Beyannamesi ve Avrupa İnsan Hakları Sözleşmesi gibi çok taraflı uluslararası belgelerde belirlenmiş olan insan hak ve özgürlükleri ile uluslararası alanda genel kabul gören insan hakları" olarak belirlenmiştir (md. 2).Bu haklar kapsamında komisyonun görevi, "TBMM başkanlığınca kendisine iletilen insan haklarının ihlale uğradı̆̆ına dair iddialar ile ilgili başvuruları incelemek veya gerekli gördüğü hallerde ilgili mercilere iletmek" (md.4/e) ile sinırlıdır, dolayısıyla komisyonun yapacağı denetim, kanun maddesinde sayılan yasal düzenlemelerin kapsamında olan hakların idare tarafından ihlali ile sınırlandırılmış olduğu gibi ihlaller karşısında doğrudan harekete geçme yetkisi de bulunmamaktadır.

1990’l1 yıllar ombudsmanlık kurumunun oluşturulmasına ilişkin dünyada gösterilen çabaların, Paris İlkeleri'nin kabulü ile paralel şekilde, ülkemizde de karşılık bulmuş halini yansıtmaktadır. Ombudsmanın gerekliliğine ilişkin tartışmaları somut adımlar izlemeye başladığında ilk adımın 57. hükümet döneminde atıldığı görülmektedir. 14.09.2000 tarihinde kurumun oluşturulmasına yönelik bir kanun tasarısı hazırlanarak TBMM'ye sevk edilmiş, ancak tasarı kadük kalmış ve ilk girişim başarısızlıkla sonuçlanmıştır (Şengül, 2007, s. 136).

$\mathrm{Bu}$ başarısız denemenin ardından ombudsmanlık kurumunun tekrar gündeme gelişi ise 2006 yılında gerçekleşmiştir. Yasal düzeyde, kurumun oluşturulmasına ilişkin yapılan düzenleme olan, 2006 tarih ve "5548 Sayılı Kamu Denetçiliği Kurumu Kanunu" hakkında Anayasa Mahkemesi'ne yapılan iptal başvurusu ile mahkemenin, 25.12.2008 tarih ve E. 2006/140, K. 2008/15 sayılı kararı ile kanunun tümünü oybirliği ile iptal edişi ikinci başarısız denemeyi oluşturmuştur (Fendoğlu, 2013, s. 24-34).

Ombudsmanlık kurumunun, kurulmasının önündeki anayasal engeli kaldırabilmek adına, bu kez, 12 Eylül 2010 tarihinde halk oylamasına sunulan anayasa değişikliği paketine dahil edilerek gündeme geldiği görülmektedir. Halk oylaması sonucu kabul edilen anayasa değişikliği paketi ile anayasanın 74. maddesinin kenar başlı̆̆ "VII. Dilekçe, bilgi edinme ve kamu denetçisine başvurma hakkı" olarak değiştirilmiş ve böylece Kamu Denetçiliği Kurumu anayasal bir statüye kavuşturulmuştur (Aktel vd,, 2013, s. 27-28).

İnsan hakları ihlalleri konusunda ayrımcılık iddialarının da yer aldığı mekanizmalar olarak inceleme ve araştırma yapmak üzere; 1990 yılında oluşturulan "TBMM İnsan Haklarını İnceleme Komisyonu", "İnsan Hakları Danışma Kurulu" (2001) ve "İnsan Hakları Danışma Kurulu” (2003) sayılabilir (Odyakmaz vd., 2016, s. 730-731). 
Ülkemizde, insan haklarının korunması ve geliştirilmesi alanında faaliyet gösteren ulusal mekanizma olarak oluşturulan ve bu anlamda T.C. Kamu Denetçiliği Kurumu'ndan belirli farklılıkları da bulunan Türkiye İnsan Hakları ve Eşitlik Kurumu'nun (TİHEK) oluşturulmasına ilişkin süreçte ise ilk adım, 2012 yılında 6332 Sayılı Kanun ile Türkiye İnsan Hakları Kurumu'nun (TİHK) kurulması olmuştur. 2016 yılında ise, Türkiye İnsan Hakları Kurumu, "6701 Sayılı Türkiye İnsan Hakları ve Eşitlik Kurumu Kanunu"'nun yürürlüğe girmesiyle mülga olmuştur (Odyakmaz vd., 2016, s. 732). Böylece 20 Nisan 2016 tarihinde 29690 sayılı Resmi Gazete'de yayımlanan "Türkiye İnsan Hakları ve Eşitlik Kurumu Kanunu" ile TİHEK kurulmuştur. Bu aşamada ilk dikkat çeken husus, TIHHEK'in yasal düzeyde oluşturulmuş olmasıdır. Bu husus, kurumu, hukuksal dayanak noktasında T.C. Kamu Denetçiliği Kurumu ile kıyaslandığında güçsüz kılmakta, yasal düzeyde yapılacak değişiklikler ile müdahalelere uğrayabilme olasıllı̆ını güçlendirmektedir.

\section{Ulusal İnsan Hakları Kurumları Türkiye Örneğinin Paris İlkelerine Uyumu Kapsamında Değerlendirilmesi}

Ulusal insan hakları kurumlarının oluşumu ve gelişim sürecinde evrensel nitelikte sayılabilecek standart ve ilkelerin neler olması gerektiği konusunda bir dizi gelişmeden bahsedilebilmekle birlikte, Paris Prensipleri, ulusal insan hakları kurumlarının sahip olması gereken temel niteliklere ilişkin çerçeveyi çizen ana metin olarak kabul edilmektedir.

Paris Prensiplerine göre, tüm ulusal insan hakları ihlalleri ulusal düzeyde oluşturulan insan hakları kurumları tarafından izlenmelidir. Bu görev ve sorumluluğu yerine getirebilmeleri adına kurumlar, yürütme gücünden bağımsız olarak en üst seviyede yasal dayanak ile yapılandırılmalı, yeterli maddi ve beşeri kaynaklarla donatılmalı, ilgili ulusal ve uluslararası kurum ve kuruluşlar ile iletişimi yüksek olmalı, görev-yetki ve sorumlulukları kuruluş amacını karşılar düzeyde olmalıdır (Paris Prensipleri). Çalışmanın bu bölümünde ulusal kurumların taşıması gereken nitelikler Paris Prensipleri kapsamında değerlendirilmektedir.

\subsection{Kuruluş Mevzuatı Açısından Kurumların İncelenmesi}

Ulusal kurumlar, insan hakları alanında koruma ve geliştirme mekanizmaları olarak görev yapmak üzere devlet tarafindan anayasal, yasal ya da idari düzenlemeler yolu ile kurulabilen resmi yapılanmalardır. Bu noktada, henüz oluşum aşamasında, kurumlara hangi seviyede bir hukuksal güvence sağlandığının önemi ortadır.

Paris İlkeleri, ulusal kurumların oluşturulması ve yetkilerinin neler olacağının düzenlenmesi noktasında ayrıntıları düzenleyen anayasal veya yasal bir metinin gerekliliğini önermektedir (Paris Prensipleri).

Kamu Denetçiliği Kurumu; "kamu hizmetlerinin işleyişinde bağımsız ve etkin bir şikâyet mekanizması oluşturmak suretiyle, idarenin her türlü eylem ve işlemleri ile tutum ve davranışlarını; insan haklarına dayalı adalet anlayışı içinde, hukuka ve hakkaniyete uygunluk yönlerinden incelemek, araştırmak ve önerilerde bulunmak" amaciyla oluşturulmuştur (KDK Kanunu, 2012, md. 1).

12 Eylül 2010 tarihinde halk oylaması ile kabul edilen anayasa değişikliği paketi kapsamında yer alan ombudsmanlık mekanizması, anayasa değişikliğinin yürürlüğe girmesinden sonra 14.06.2012 tarihinde kabul edilen 6328 sayılı Kamu Denetçiliği Kurumu Kanunu ile ülkemizde de kurumsal bir yapıya kavuşmuştur.

29.06.2012 tarihinde Resmi Gazetede yayımlanarak yürürlüğe giren kanun, kapsam yönünden incelendiğinde, T.C. Kamu Denetçiliği Kurumu'nun kuruluş, görev ve çalışma usullerine ilişkin ilkeleri düzenlediği görülmektedir. Kurum üyeleri, üye oluşumu ve özlük haklarına ilişkin hükümler de yasal statüde düzenlenmiştir (md.2).

6328 sayılı Kanun ile kuruma, şikâyet başvurularını, içeriklerine göre, ulusal mevzuat ve başta İnsan Hakları Evrensel Beyannamesi olmak üzere Paris İlkeleri ve taraf olunan diğer 
uluslararası sözleşmeler dikkate alınarak; "insan haklarına dayalı adalet anlayışı" perspektifinde ve aynı zamanda da "iyi yönetişim" ilkeleri gözetilerek inceleme ve önerilerde bulunma görevi verilmiştir (KDK 2017-2021 Stratejik Planı, s. 23).

Kuruluş mevzuatı açısından Türkiye İnsan Hakları ve Eşitlik Kurumu'nun, Kamu Denetçiliği Kurumu'nun aksine anayasal bir dayanağa sahip olmadığı ve kurumun yasal statüde oluşturulduğu görülmektedir. 20 Nisan 2016 tarih 29690 sayılı Resmi Gazete'de yayımlanan 6701 sayılı Kanun ile Türkiye İnsan Hakları ve Eşitlik Kurumu'nun teşkilat, görev ve yetkilerine ilişkin esaslar düzenlenmiştir.

Kanun, amaç ve kapsam bakımından; "insan onurunu temel alarak insan haklarının korunması ve geliştirilmesi, kişilerin eşit muamele görme hakkının güvence altına alınması, hukuken tanınmış hak ve hürriyetlerden yararlanmada ayrımcılığın önlenmesi ile bu ilkeler doğrultusunda faaliyet göstermek, işkence ve kötü muameleyle etkin mücadele etmek ve bu konuda ulusal önleme mekanizmasl görevini yerine getirmek üzere Türkiye Insan Haklarl ve Eşitlik Kurumunun kurulmasl, teşkilat, görev ve yetkilerine ilişkin esasları" düzenlenmektedir (md.1).

$\mathrm{Bu}$ amaç ve kapsam incelendiğinde ulusal önleme mekanizması görevini üstlenerek insan haklarının korunup geliştirilmesi, ayrımcılık ve işkence-kötü muamele ile mücadelenin tek bir kurumsal yapı içerisinde toplandığı görülmektedir.

Kurumun iş ve işlemlerine yönelik olarak ayrıntılı düzenleme ise "Türkiye İnsan Hakları ve Eşitlik Kurumu Kanununun Uygulanmasına Illişkin Usul ve Esaslar Hakkında Yönetmelik" ile yapılmış; "kurum personelinin uyacakları mesleki ve etik ilkeler, komisyonların ve dairelerin oluşumu, çalışma esasları, kuruma başvuruların nasıl yapılacağı, verilecek karar türleri, özgürlüğ̈̈nden mahrum bırakılan ya da koruma altına alınan kişilerin bulundukları yerlere haberli veya habersiz gerçekleştireceği ziyaretler ile özgürlüğünden mahrum bırakılan ya da koruma altına alınan kişilerin başvurularının incelenmesi ve sonuçlandırılmasına iliş̧kin usul ve esaslar" düzenlenmiştir.

\subsection{Kurumsal Özellikler Bakımından Karşılaştırma}

İnsan hakları alanında ulusal koruma mekanizmaları olarak faaliyet gösteren kurumlar, yapıları itibariyle her ülkede çeşitlilik gösterseler de sahip oldukları ortak ideal insan haklarının korunması ve geliştirilmesidir.

Kurumlar oluşturulurken, üstlendikleri görev ve yetkiler itibariyle işlevlerini en verimli şekilde yerine getirebilmelerine olanak sağlayacak özellikler ile donatılmaları gerekmektedir.

\subsubsection{Bă̆ımsızlık}

İnsan hakları alanında faaliyet gösteren ulusal kurumların çalışmalarını etkin bir şekilde yerine getirebilmeleri için, bağımsız bir şekilde yapılandırılmış olmaları gerekmektedir. Bağımsızlık özelliğinin gerekliğinden kasıt, kurumların devlet organlarının etkisinden ne derece uzak şekilde faaliyet gerçekleştirebildikleri ile ilişkilidir.

T.C. Kamu Denetçiliği Kurumu "bağımsızlık" açısından incelendiğinde; kuruma resmi anlamda bağımsızlığını sağlayan nokta olarak, kurumun kuruluş, görev ve çalışma usullerine ilişkin ilkelerin 6328 sayılı Kamu Denetçiliği Kurumu Kanunu'nda düzenlendiği görülmektedir.

Kamu Denetçiliği Kurumu, "Türkiye Büyük Millet Meclisi’ne bağgl, kamu tüzel kişiliğine haiz, özel bütçeli ve merkezi Ankara'da bulunan bir kuruluştur" (md.4/1). Bu düzenleme ile ombudsman geleneğinde genel eğilim olan "parlamentoya bağlı olma" niteliğine sadık kalınmış ve kurum idare karşısında bağımsız bir statü kazanmıştır. Halkın seçtiği temsilcilerden oluşan TBMM'ye bağlı oluşu kurumun demokratik meşruiyetinin de kaynağıdır. $\mathrm{Bu}$ genel eğilim ile ombudsmanlık kurumuna, idarenin eylem ve işlemlerini gerçekleştirirken dikkate almak zorunda kalacağı bir otorite olma statüsü kazandırılmıştır. Bu hususlar dikkate 
alındığında T.C. Kamu Denetçiliği Kurumu'nun, parlamento adına ve onun desteğine sahip olmanın verdiği moral gücü ile denetim ve gözetim yapma işleviyle donatıldı̆̆ görülmektedir (Şengül, 2007, s. 138).

Kanunun 12. maddesi, kurum üyelerine ilişkin olarak yapılan düzenleme, "Hiçbir organ, makam, merci veya kişi Başdenetçiye ve denetçilere görevleriyle ilgili olarak emir ve talimat veremez, genelge gönderemez, tavsiye ve telkinde bulunamaz". "Başdenetçi ve denetçiler, görevlerini yerine getirirken tarafsizlı ilkesine uygun davranmak zorundadırlar" (md. 12/2) kurum üyelerinin bağımsızlık ve tarafsızlığını teminat altına almaya yönelik olarak yorumlanabilir.

Paris Prensipleri, ulusal insan hakları kurumlarının yeterli mali kaynak ve alt yapı ile donatılmaları gerekliliği üzerinde de durmaktadır. $\mathrm{Bu}$ sebeple ulusal kurumların bağımsızlıklarına etki edecek bir mali yapı ve denetim altında tutulmamaları gerekmektedir. T.C. Kamu Denetçiliği Kurumu, mali açıdan, "özel bütçeli" bir kurum olarak yapılandırılmıştır. Tanımı itibariyle özel bütçe, "bir bakanlı̆̆a bağll veya ilgili olarak; belirli bir kamu hizmetini yürütmek üzere kurulan ve bu sebeple kendisine gelir tahsis edilen, bu gelirlerden harcama yapma yetkisine sahip, kuruluş ve çalışma esasları özel kanunla düzenlenen kamu idarelerinin bütçesi"dir (Özdemir, 2014, s. 67-68). Bütçe yapısı yönüyle Kamu Denetçiliği Kurumu, yasama organının genel yapısından uzak kalmaktadır.

Türkiye İnsan Hakları ve Eşitlik Kurumu, bağımsızlık niteliği açısından ele alındığında; "idari ve mali özerkliğe sahip, özel bütçeli, kamu tüzel kişiliğine sahip ve Cumhurbaşkanının görevlendireceği bakan ile ilişsili" olarak yapılandırılmıştır (md.8/1). Kurum bütçesinin Hazine ve Maliye Bakanlığı kontrolünde tahsis edilmesi ise mali bağımsızlık adına bir zayıflık olarak ifade edilebilir.

Kurum; kurul, başkanlık ve bürolardan oluşmakta (md.8/2) ve karar organı olan "kurul" Cumhurbaşkanı tarafından atanan on bir üyeden oluşmaktadır (md 10/2). Karar organı üyelerinin Cumhurbaşkanı tarafından atanıyor olması kurumun yürütme gücüne karş1 bağımlılığı noktasında endişelere sebep olmaktadır. Buna karşın, kurulun, çalışmalarında bağımsız ve tarafsız olduğunun teminatı olarak gösterilecek düzenleme ise "kendisine yasal olarak verilen görev ve yetkilerini kendi sorumluluğu altında, bağımsız olarak yerine getireceği, görev alanına giren konularda hiçbir organ, makam, merci veya kişinin emir ve talimat, tavsiye ve telkini altında olmadĭ̆gl"dır (md.10/1).

\subsection{2. Üye Oluşumu ve Teminatları}

\subsubsection{1. Üye Yapısı}

Paris İlkelerine göre, ulusal insan hakları kurumlarının üye oluşumu, "insan haklarının korunması ve geliştirilmesiyle ilgili sivil toplum güçlerinin çoğulcu bir biçimde temsiline olanak sağlayacak güvenceler kapsamında seçim veya başka bir yol ile belirlenebilir".

Üye oluşumu açısından Kamu Denetçiliği Kurumu; 1 Başdenetçi ve Başdenetçiye kanunda verilen görevlerin yerine getirilmesinde yardımc1 olmakla görevli 5 denetçiden oluşmaktadır. Kuruma gelen şikâyetleri inceleme-araştırma ve idareye önerilerde bulunma görevi Başdenetçi'ye aittir. Denetçiler arasında iş bölümünü düzenleme açısından kadın ve çocuk haklarına ilişkin ayrı bir düzenlemeye gidilmiş ve Başdenetçiye "birisi kadın ve çocuk hakları alanında görevlendirilmek üzere denetçiler arasındaki iş bölümünü düzenleme" yetkisi tanınmıştır (md. 7/1).

Başdenetçi ve denetçilerde aranan nitelikler kanunun 10. maddesinde sıralanmıştır. Genel eğilim olarak ombudsmanlık kurumuna hukuk fakültesi mezunlarının seçildiği görülmektedir. Bu noktada ülkemiz uygulamasında göze çarpan farklılık, dört yıllık eğitim veren siyasal bilgiler ve iktisadi ve idari bilimler fakültesi mezunlarının da Başdentçi ve denetçi olabilmesine olanak tanınmasıdır. Dikkat çeken bir diğer husus da Başdenetçi olarak seçilecek 
kişinin 50 yaşını ve denetçi olarak seçilecek kişilerin ise 40 yaşını doldurmuş olmaları ve mesleki tecrübe itibariyle kamu ve özel sektörde on yıl çalışmış olmaları şartıyla kamu denetçisi olabilmelerine imkân tanınmasıdır. Ülkemizde tercih edilen bu yönlü düzenlemelerin, bu kişilerin mesleki tecrübelerinin kuruma sağlayacağ 1 faydadan yararlanmak olarak yorumlanabilir (Şengül, 2007, s. 139).

Üye oluşumu açısından TİHEK incelendiğinde; kurul, başkanlık ve bürolar şeklinde yapılandırıldığ 1 görülmektedir. Kurul, kurumun karar organı olarak üye seçiminin tamamı Cumhurbaşkanı tarafından yapılmaktadır (md.10/2). Bu düzenleme Cumhurbaşkanlığı hükümet sistemine geçilmeden önce, 3 üye Cumhurbaşkanı tarafindan ve 8 üye bakanlar kurulu tarafından seçilecek şekildedir. Üye seçimi konusunda, TİHEK mevzuatında 02.07.2018 tarihli 703 sayılı KHK ile yapılan değişiklik, kurul üyelerinin çoğulcu bir şekilde belirlenmesine ilişkin "insan hakları alanında çalı̧̧malar yürüten akademisyenler, STK'lar, sendikalar ve mesleki kuruluşlar ile avukatlar, görsel ve yazılı basın mensuplarının göstereceği adaylar veya üyelik için başvuruda bulunanlar arasından" şeklindeki düzenlemeyi kanundan çıkartmakla birlikte üyelerin görev süresinin dört yıl olduğunu ve tekrar seçilmelerine ilişkin düzenlemenin de kaldırılmasıyla üye oluşumunda çoğulculuğun ve görev sürelerinin de artık yürütmenin takdirinde olduğuna yönelik eleştirilerin önünü açmıştır (Didinmez, 2020, s. 151). Bununla birlikte, görev süresine ilişkin olarak belirlenen dört yılın bitimi itibariyle kaç kez yenileme yapılabileceği de düzenlenmemiştir. Düzenlemenin liyakat ilkesini zedeleyebilecek boyutu ise insan hakları gibi özel bilgi, deneyim ve uzmanlık gerektiren hassas bir konuda üyelerin yeterli donanıma sahip olup olmadığı noktasında oluşabilecek kaygıdır.

Kurum üyeleri hakkında dikkat çeken bir diğer nokta da TIHHEK üyeleri için 6701 sayıl1 kanunun 10. maddesinde 657 Sayılı Devlet Memurları Kanunu'na "Kurul üyelerinin 657 Sayll Kanun'da sayılan ilgili şartları taşımaları gerektiği"' şeklinde yapılan atıftır. TİHEK'in idare karşısında hem kurumsal hem de personel açısından güvenilirliği ve bağımsızlığı, insan hakları alanındaki faaliyetleri denetleyen bir kurumun çalışanlarının birer devlet memuru değil bağımsız bir kurumun bağımsız çalışanları olarak konumlandırılmaları daha uygun gözükmektedir (Duman, 2017, s. 137).

\subsubsection{2. Çoğulculuk}

Çoğulculuk, modern dünyamızın karmaşık yapı ve ilişkileri içerisinde yer alan farklı talep ve çıkarların ifade şansı bulması ve bu taleplerin siyasal kararların alınması sürecine yansımasına imkân veren bir kavramdır (Köker, 2006, s. 201).

Ele aldığımız kurumların oluşturulması süreci, öncesi ve sonrası itibariyle toplumun tüm kesimlerine ifade şansını tanıyacak şekilde yapılandırılmalıdır. 6701 Sayılı kanun hazırlık süreci kapsamında incelendiğinde, sivil toplum kuruluşlarının (STK) görüşlerinin alındığı iddia edilmişse de pratikte ve STK'ların eleştirilerinde aksi ifade edilmektedir. TİHEK 'in oluşum sürecinde, dönemin başbakan yardımcısı Numan Kurtulmuş, TIHHEK'in “işkenceyi önleme ve kamu ve özel sektörün içerisinde karşılaşılabilecek ekonomik ve sosyal haklara erişimdeki ayrımcılı̆̆a dayalı olası hak ihlallerine karşı" kurulması hakkındaki kararı kamuoyu ile paylaşmışır. STK'ların beyanı ise, insan hakları alanında faaliyet gösterecek bu kurumdan bu duyuru ile beraber basın kanalı ile haberdar olduklarıdır. Adeta sürecin lansmanı yapılmış; karar alınmış, süreç planlanmış ve kamuoyuna duyurulmuştur. Böyle bir ifade, ulusal önleme mekanizması olarak faaliyet gösterecek bir kurumun oluşum sürecinin katılımcılık garantörü olan STK'ların, bu sürecin tamamen dışında bırakıldığının beyanı olarak gösterilmektedir. Bu durumda henüz tasarı aşamasında Paris İlkeleri ve Seçmeli Protokol' ile örtüşmeyen noktaların ortaya çıktığı da sıklıkla savunulmuştur (Duman, 2017, s. 29).

\subsubsection{3. Üyelik Teminatları}

Paris İlkeleri, ulusal insan hakları kurumları üyelerinin ifa ettikleri görevleri kapsamında sahip olacakları üyelik teminatı ve dokunulmazlıklarına ilişkin bir düzenlemeye yer 
vermemiştir, ancak üyelerin, görevleri sebebiyle yerine getirdikleri eylem ve davranışları nedeniyle hukuki ve cezai olarak sorumlu tutulmamaları etkin çalışma şartlarının garantörüdür. Burada, üyelere tanınacak dokunulmazlık, onlara ayrıcalık sağlamak değil serbestçe faaliyet göstermelerine olanak tanımak demektir. Bununla birlikte, üyelere tanınan dokunulmazlık resmi bağımsızlığı sağlamanın da yasal şeklidir (Açık, 2011, s. 127-129).

Ülkemiz yapılanması incelendiğinde, her iki kurumun üyeleri için de görevlerini yerine getirirken dokunulmazlık sağlanması konusunda düzenlemeler mevcut değildir. Kamu Denetçiliği Kurumu Kanunu Başdenetçi ve denetçilerin görev süreleri ile tekrar seçilip seçilemeyeceklerini düzenlemiş, ancak görevden alınma şartlarına yer vermemiştir. TİHEK açısından ise, 6701 sayılı kanuna göre; "başkan, ikinci başkan ve üyelerin görev süreleri dolmadan herhangi bir nedenle görevlerine son verilemeyeceği" (md 10/8), ancak aynı fikrada yedi bentte sayılan hallerinin tespiti durumunda, üyeliklerine son verileceği belirtilmiştir.

\subsection{3. Çalışma Yöntemleri}

Paris İlkeleri, ulusal insan hakları kurumlarının çalışma biçimlerine ilişkin olarak, ulusal kurum; "kendi yetki alanında bulunan herhangi bir meseleyi özgürce mütalaa edebilmeli, gerekli her türlü bir bilgi ve belgeyi edinmeli, bütün kişileri dinlemeli, tavsiyelerini kamuoyuna duyurmak amacıyla düzenli olarak bütün üyelerinin katılımıyla toplanmalıdır. Bunun için gerektiğinde üyeleri arasından çalışma grupları oluşturma ve kurumun işlevlerini yerine getirmesinde yardımcı olmak üzere yerel ve bölgesel birimler kurmalıdır. Insan haklarının geliştirilmesi ve korunmasından sorumlu makamlarla istişareyi sürdürmeli, insan haklarının geliştirilmesi ve korunması alanlarında uzmanlaşmış sivil toplum kuruluşları ile ilişkilerini geliştirmelidir" şeklinde bir düzenlemeye yer vermiştir.

Kamu Denetçiliği Kurumu'na gelen şikâyet başvuruları kapsamında, kurumun Başdenetçi veya denetçilerinin, ilgili idareden bilgi ve belge isteyebileceği (md.23/1), özel veya teknik bilgi gerektiren durumlarda ise alanında uzman kişilerden bilirkişi görevlendirebileceği (md.24/1) ve tanı veya ilgili kişilerin dinlenmesi (md.25/1) kararı verebileceği Kamu Denetçiliği Kurumu Kanununun Uygulanmasına İlişkin Usul ve Esaslar Hakkında Yönetmelik ile düzenlenmiştir. Bu kapsamda incelenecek bir örnekte, İstanbul'da yaşanan gezi park1 olaylarında, gösterilerde bulunanlara yönelik hak ihlalleri iddialarına yönelik başvurunun incelenmesi sürecinde, kamu başdenetçisi ve ilgili kamu denetçisi tarafından gerçekleştirilen inceleme ve araştırmalar kapsamında ilgili bireyler, tanıklar, İstanbul Valisi, İstanbul Büyükşehir Belediye Başkanı, sivil toplum kuruluşlarının ve meslek odalarının temsilcileri ile birebir görüşmeler gerçekleştirilmiş, ses ve görüntü kaydı incelemeleri yapılmış ve bilirkişi mütalaası ile teknik destek alınmıştır (KDK Karar No: 2013/90).

Çalışma yöntemi açısından Kamu Denetçiliği Kurumu'nun sadece başvuru üzerine harekete geçebilmesi yani resen harekete geçme yetkisinin bulunmaması kurum adına denetiminin etkinliğini azaltan bir düzenlemedir. Bununla birlikte Kamu Başdenetçisine, başvuru şartı gerekmeksizin, idarenin faaliyetleri ile ilgili gerekli gördüğü ya da toplumun genelini ilgilendiren konularda "özel rapor" hazırlatma yetkisi verilmiştir (ombudsman.gov.tr/sıkça sorulan sorular5).

Yerinde inceleme yapma yetkisi yönünden, KDK, başvuru konusunun temel insan hak ve özgürlüklerine, kadın-çocuk haklarına ilişkin olması halinde yerinde inceleme yapabilmektedir. Kamuyu ilgilendiren genel konulara ilişskin olarak ise, şikayetçi veya şikayet edilen idarenin talebi olması halinde, yerinde inceleme yapılabilmektedir (ombudsman.gov.tr/sıç̧a sorulan sorular28).

Çalışma biçimi açısından TİHEK, Kamu Denetçiliği Kurumu'na kıyasla daha güçlü olanaklara sahiptir. Bu kapsamda, çalışma grupları ve yerel-bölgesel birimler oluşturabilmekte ve sivil toplum ile ilişkiler kurabilmektedir (6701 sayılı kanun/md. 14). 
Yerinde inceleme yapma yetkisinin var olup olmadığ kapsamında değerlendirme yaptığımızda ise, 6701 Sayılı Kanun ile TIHHEK'e yerinde inceleme yapma yetkisi verildiği görülmektedir. TİHEK'in, görev alanına giren konularla ilgili olarak; özgürlüğünden mahrum bırakılan ya da koruma altına alınan kişilerin bulundukları yerleri ziyaret edebileceği, kötü muameleye maruz kaldığını iddia eden kişi ya da kişilerle görüşmeye yetkili olduğu ve ayrıca ilgili kamu kurum ve kuruluşları ile diğer gerçek ve tüzel kişilerin de TïHEK'in incelemeler kapsamındaki çalışmalarını kolaylaştırmak ve taleplerini gecikmeksizin yerine getirmek zorunda oldukları (md.19/2) düzenlenmiştir.

Basında yer alan haberlerden, TİHEK'in ilk ziyaretini 17 Ekim 2017 tarihinde Rize Valiliği'’nde gerçekleştirdiği ve İl Emniyet Müdürlüğü binasındaki nezarethaneler ile Rize L Tipi Kapalı Ceza İnfaz Kurumunda incelemelerde bulunduğu öğrenilmiştir (Habertürk, 2017). Yine, yerinde inceleme yetkisinin kullanımına örnek teşkil eden bir olayda TİHEK; İran, Suriye ve Afgan uyruklu kişilere yönelik "İ̇anll, Suriyeli ve Afgan müşteriler bu dükkâna giremez, girerse dayak yer" şeklinde bir afişe dayanarak basında yapılan haberler üzerine resen inceleme başlatmış ve Denizli'de kurum uzmanlarınca yerinde inceleme yapılmıştır. Kurum, 2019/29 numaralı kararında ayrımcılık yasağı ihlali yapıldığına hükmetmiş ve ihlali yapan kişi hakkında 1000TL idari para cezasına hükmetmiştir, para cezası ise kişinin ekonomik durumu ve pişmanlığı dikkate alınarak uyarı cezasına dönüştürülmüştür (Milliyet, 2019).

\subsubsection{Erişilebilirlik}

Erişebilirlik, sunulan hizmetlerden faydalanma ve beraberinde hizmetlere katkıda da bulunabilme olanaklarına sahip olmayı ifade eden bir kavram olarak her türlü hakkın kullanımında kilit bir rol üstlenmektedir (Çağlar, 2012, s. 549). Ulusal insan hakları kurumlarına erişebilirlik kolaylığı, bu kurumların, bir yandan sahip olduğu alternatif erişim kanallarının çeşitliliği yani kuruma ve bilgiye ulaşabilme açısından değerlendirilebilirken bir yandan da toplumun farklı kesimleri ve özellikle dezavantajlı kesimlerinin erişim ve temsilini sağlayabilmiş olması ile birlikte değerlendirilmelidir.

Kamu denetçiliği kurumu, erişilebilirliği açısından incelendiğinde; kanunda, menfaati ihlal edilen gerçek ve tüzel kişilerin kuruma başvuru yapabileceği düzenlenmiştir (md. 17/1). Başvuru için süre şartı 6 aydır. Dernek, vakıf, şirket gibi tüzel kişiler ise vekilleri aracılığı ile başvuru hakkını kullanabilmektedir. Menfaat ihlali şartı, çocuk haklarına ilişkin yapılacak başvurularda aranmamaktadır. Bunu desteleyen bir düzenleme de 18 yaş altı için alternatif bir erişim yolu olarak, "www.kdkcocuk.gov.tr" internet adresi üzerinden kamu denetçiliği kurumuna başvuru yapılabilmesidir (Ombudsman.gov.tr/rehber-sikca-sorulan-sorular6). Burada dikkati çeken husus, kuruma yapılacak şikâyetin doğrudan başvuru sahipleriyle ilgili olması gerekliliği bulunmamasıdır. Toplumun dezavantajlı kesimleri olarak nitelenebilecek ve son dönemde de sıklıkla gündemde olan kadına yönelik şiddet iddialarına ilişkin olarak mağduriyetlerin önüne geçilebilmesi adına kuruma erişilebilirliği arttırabilmek için "kadin.ombudsman.gov.tr" olarak ayrı bir erişim ve bilgilendirme mekanizması oluşturulmuştur. Böyle bir mekanizmanın kurumun öncelikleri arasına girmesi bu alandaki hak arama bilincinin arttırılması adına önemli bir gelişmedir.

Kamu Denetçiliği Kurumu'na, kanunda sayılan şartlara uygun olarak, Türkçe dilekçe ile başvuru yapılabileceği gibi elektronik ortamda e-başvuru veya diğer iletişim araçlarıyla da yönetmelikte belirtilen şartlara uygun olmak kaydıyla (md. 17/1) başvuru yapılabilmektedir. Kuruma, herhangi bir ücret ödemeksizin illerde valilikler, ilçelerde kaymakamlıklar aracılığıyla da başvuru yapılabilir (md. 17/5 ve md. 17/6). Düzenlenen bu hususlar, mağdurlar açısından, kuruma başvuruyu teşvik edecek kolay ve masrafsız erişimi sağlar niteliktedir. Başvuru noktasında önemli husus, kuruma başvuru yapılabilmesinin 2577 sayılı İdari Yargılama Usulü Kanun'unda öngörülen idari başvuru yolları ile özel kanunlarda düzenlenen zorunlu idari başvuru yollarının tüketilmesi (md. 17/4) şartına bağlanmasıdır. Bu düzenlemeye ek olarak 6328 Sayılı Kanun'un 17'nci maddesinin 4'üncü fikrası, “başvuran açısından, konuyla ilgili 
telafisi güç ve imkânsız zararların doğma ihtimalinin bulunması durumunda, idari başvuru yolunun tüketilmesi şartı aranmamaktadır" ifadesine de yer vermektedir.

Dava açma süresi açısından, başvuru sürecinin nasıl olacağı da bir diğer önemli husustur. Kural olarak, kuruma başvuran için dava açma süresi başvurunun yapıldığ 1 andan itibaren durmaktadır. KDK'nın başvuruyu inceleyerek karara bağlanması ve kararın ilgiliye tebliğ edildiği tarihten itibaren dava açma süresi kaldığı yerden işlemeye devam etmektedir. Bir örnek ile açıklamak gerekirse, Aksaray'da yaşayan vatandaş "A” İl Emniyet Müdürlüğünde çalışmakta olan polis memuru "B" nin kendisini 01 Ocak 2016 tarihinde darp ettiğinden bahisle 11 Ocak 2016 tarihinde Kamu Denetçiliği Kurumu'na şikâyet başvurusunda bulunmuştur. Görüldüğü üzere dava açma süresi 10 gün işlemiştir. Dava açma süresi, ombudsmana başvuru tarihi olan 11 Ocak 2016 tarihinden itibaren durmuştur. Kurum tarafindan verilecek karar sonrasında ise dava açma süresinden arta kalan süre devam etmektedir. Kuruma yapılan şikâyet başvurularının sonuçlandırılmasına ilişkin süre ise, başvurunun kayıtlara alınmasından itibaren en geç 6 ay içerisinde sonuçlandırılacak şekilde belirlenmiştir. Başvurunun kapsamlı bir araştırmayı gerektirmesi nedeniyle 6 aylık süre içerisinde inceleme ve araştırma sonuçlandırılamazsa gecikmenin başvurana yazılı olarak bildirilmesi gerekmektedir (Ombudsman.gov.tr/rehber-sikca-sorulan-sorular14).

Erişilebilirlik açısından TİHEK, ayrımcılık yasağı ihlali kapsamında zarar gördüğünü iddia eden her gerçek ve tüzel kişinin başvurusuna açıktır (md. 17/1). Kuruma başvurular dilekçe ile yapılabilmekte ve alternatif bir yol olarak kurumun gerekli gördüğg̈ yerlerde açtığ bürolara da elden teslim edilebilmektedir. Bu başvuru yoluna ek olarak posta, e-posta veya faks gibi erişim yolları da kullanılabilmektedir. İhlal iddialarına ilişkin başvurular, illerde valilikler, ilçelerde kaymakamlıklar aracılığıyla da yapılabilir. Başvurular herhangi bir ücrete tabi değildir. Başvuru hakkının etkin bir şekilde kullanılmasına hiçbir surette engel olunamaz (md.17/1). Böylece kuruma başvurular kolay bir şekilde yapılabilmekte ve erişim şartlarının alternatifliliği sağlanmaktadır.

TİHEK'e başvuru yapabilmek için öncelikli şart, ilgililerin kanuna aykırı olduğunu iddia ettikleri uygulamanın düzeltilmesini ilk olarak ilgili taraftan talep etmesidir. Bu taleplerin reddi veya otuz gün içerisinde cevap verilmemesi hâlinde TİHEK'e başvuru yapılabilir, ancak telafisi güç veya imkânsız zararların doğması ihtimali bulunan hallerde, başvurular şart aranmadan kabul edilmektedir (md. 17/2).

TİHEK'i, Kamu Denetçiliği Kurumu'ndan ayıran önemli bir yetki alanı, resen inceleme yapabilme yetkisine sahip olmasıdır. Bu noktada ihlallere ilişkin inceleme süreci, resen inceleme kararının alındığı tarihten itibaren en geç üç ay içinde sonuçlandırılmalıdır (md. 18/1).

Paris Prensipleri, erişebilirlik açısından, ulusal insan hakları kurumlarının sivil toplum ile ilişkilerine de ayrı bir önem atfetmektedir. Sivil toplum kuruluşlarının sahip olduğu temsil gücü ve erişim ağı düşünüldüğünde özellikle çocuklar, kadınlar, engelliler ve sığınmacılar gibi güçsüz grupların kurumlara erişebilirliğinin önemi ön plana çıkmaktadır. Bu noktada bir diğer önemli husus da ulusal kurumların sivil toplum ile olan iş birliğinin ne derece etkin işlediğidir. Ulusal kurumların sivil toplum kuruluşları ile toplantı, proje ya da çalıştay gibi etkinlikler ile hangi sıklıkla iletişime girdiği ve bu etkinlikler neticesinde sivil toplum örgütleri ile vereceği birliktelik imajı mağdurların kuruma güveni arttıracağı gibi olası ihlalleri daha önleme aşamasında bertaraf ederek kurumun etkinliğini arttıracaktır.

Sivil toplum ile olan işbirliğinde kurumların yazılı-görsel basın ve özellikle de sosyal medya ile etkileşimi kurumların tanınırlığı açısından da oldukça önemlidir. Medyaya yönelik ziyaretler ve düzenlenecek etkinlikler ve bunların günümüz şartlarında online platformlarda da gerçekleştirilebilir olması kurumların etki alanını genişletebilmesi açısından değerlendirilmesi gereken firsatlar niteliğindedir. Görünür ve bilinir bir ulusal insan hakları kurumunun etkinliği çalışmalara duyulan güven ve moral gücünü arttıran önemli bir unsurdur (Sobacı ve Köseoğlu, 2016, s. 108). 
Ulusal kurumların sosyal medya ile ilişkisi ve verdikleri kararlarının günümüzde etkinliği yüksek derecede olan sosyal medya hesapları üzerinden de ön plana çıkarılması şikâyet başvuruları ve karaların neler olabileceği noktasında kamuoyunda bir hak arama bilincinin oluşması açısından itici bir güç durumundadır. Ulusal kurum ve medya ilişkileri adına güzel bir örnek olarak gösterilebilecek ve yazılı, görsel ve sosyal medyada gündeme taşınan örnek başvuruda; 17.01.2020 tarihinde orta-ağır düzey zihinsel yetersizlik özel eğitim öğrencisi olan A. H. Y. T. için epilepsi rahatsızlığı da bulunması sebebiyle özel eğitim talebinin kabulü, ancak okul servisi talebinin ise kamu zararı sayılarak reddedilmesi üzerine eğitim hakkının zihinsel ya da bedensel engelli çocuklar aleyhine ihlal edildiğine yönelik olarak TíHEK'e yaptığ ayrımcılık yasağı ihlaline yönelik başvurusunun ulusal ve uluslararası mevzuat hükümleri kaynak gösterilerek ayrımcılık yasağ 1 ihlali yapıldığg ve muhatap K. Kaymakamlığ1 İlçe Müdürlüğü hakkında idari para cezası uygulanmasına karar verilmesine (TİHEK 2020/143 Sayılı Karar) ilişkin örnek karar özellikle toplumun zayıf kesimlerinin seslerini duyurabilmeleri adına emsal teşkil edebilecek nitelik ve baskı gücü ile medya gündemine taşınmış bir örnektir. $\mathrm{Bu}$ gibi örneklerin temsil gücünün çoğaltılması, eğitim hakkı gibi zincirleme etkiye sahip olarak bir dizi hak ihlaline de gebe kalabilecek mağduriyetlerin sesini duyurabilmesine potansiyel mağdurlar adına özellikle önem atfedilmelidir.

$\mathrm{Bu}$ sebeplerle, mağdurlar, ulusal kurumlara başvuru prosedürleri hakkında bilgilendirilmeli, kurumlar mağdurlar açısından kolay erişilebilir olmalı ve bu amaçla gerekirse bölgesel veya yerel birimler oluşturmal, sosyal medya desteği ile kurumsal tanıtım videoları, basın toplantıları ve gerçekleştirilen faaliyetlerin paylaşımı, tamamlanan bir raporun ilgililere duyurulması vb. halkı bilgilendirme çalışmaları yapılmalıdır. Ayrıca, bu imkânlar binlerce kişiye hızlıca ulaşılarak zaman ve kaynak tasarrufu sağlamak açısından da işlev görmektedir.

\subsection{Görev, Yetki ve Sorumluluk Alanları Açısından Karşılaştırma}

Paris İlkelerine göre, insan hakları alanında faaliyet gösteren ulusal kurumların temel görevi, insan haklarının geliştirilmesi ve korunmasıdır. Kurumların bu amaç etrafındaki görevleri anayasalarda yer almalı veya hukuksal geçerliği olan bir metinle açık şekilde saptanmalıdır.

$\mathrm{Bu}$ noktada belirtilmesi gereken, ulusal insan hakları kurumlarının görevinin yönetimin hata ve eksikliklerini ifşa etme ya da yönetime karışma amacı taşımadığı gibi, aksine, yönetime ayna tutarak mağdur olduğunu düşünenlerin başvurularını değerlendirmek, iletmek ve hak aramalarına yol göstererek çözüm sürecini işlevsel k1labilmektir (Pickl, 1986, s. 42).

6328 sayılı Kanun'un 5. maddesi Kamu Denetçiliği Kurumu'nun görevlerini düzenlemiştir. Kanun maddesi, kurumu "idarenin işleyişi ile ilgili şikâyet üzerine, idarenin her türlü eylem ve işlemleri ile tutum ve davranışlarını; insan haklarına dayalı adalet anlayışı içinde, hukuka ve hakkaniyete uygunluk yönlerinden incelemek, araştırmak ve idareye önerilerde bulunmak" görevi ile yükümlü kllmıştır. Kanun maddesi incelendiğinde kurumun idare ile ilgili olan tüm uyuşmazlıklar ile ilgili olarak başvuru kabul edebileceği görülmektedir.

$\mathrm{Bu}$ şekilde kapsamlı ve geniş bir görev ve yetki alanının belirlenmesi gerekliliği ile birlikte, bazı uygulama örneklerinde, insan haklarını ihlal potansiyele sahip olan örneğin askeri güçler ya da benzeri güvenlik güç ve uygulamalarına da rastlanabilmektedir. Bu durum yalnızca özellikli alanlarda faaliyet gösteren ombudsmanlık kurumlarının da gerekliliğini ortaya koymaktadır. Ülkemiz pratiğinde tercih edilenin genel amaçlı ombudsmanlık kurumu olması hususu, insan haklarının korunması gibi hayati bir konuda, bu tarz kurumların eylem ve işlemlerinin ulusal kurumların inceleme alanı dışında bırakılması açısından değerlendirildiğinde koruma mekanizmasının itibar ve güvenilirliğini zedeleyen bir durumdur. Olması gereken, ulusal kurumların yetki alanının güvenlik vb. güçler de dâhil olmak üzere, insan hakları ihlalinde bulunan ve bulunması muhtemel tüm devlet kurumları ile personellerini kapsayacak şekilde düzenlenmesidir. Bununla birlikte, ihlaller karşısında korunması hassas bir öneme sahip olan, yani toplumda hak ihlaline uğrama potansiyeli açısından dezavantajlı kesimlerin koruması 
da ulusal kurumlara tanınan yetki alanının genişliği anlamında önemlidir. Yürütülen faaliyetlerin, açıklık ve hesap verebilirlik ilkeleri işletilerek faaliyet raporları/kararlar şeklinde kamuoyuna açık olacak şekilde yayımlanması ve sonuçlar hakkında kamuoyuna hesap vermeyi (Açık, 2011, s. 147) içerecek şekilde düzenlemeler yapılması da kurumlara yönelik toplumsal algıda moral değerini yükseltecek unsurlardır.

Ülkemiz uygulamasında, ulusal kurumların, hangi kurum/konularda eylem ve işlemleri inceleme yetkisine sahip olduğu noktasında bazı istisnalara rastlanmaktadır. Cumhurbaşkanının anayasanın 105. maddesine dayanarak tek başına yaptığı işlemler ve resen imzaladığ 1 kararlar/emirler, yasama yetkisinin kullanılmasına ilişkin işlemler, yarg1 yetkisinin kullanılmasına ilişkin kararlar ve Türk Silahlı Kuvvetleri'nin "sırf askeri nitelikteki" faaliyetleri kurumun görev alanı dışında bırakılmıştır (md. 5).

$\mathrm{Bu}$ istisnaları farklı ülke uygulamaları ile karşılaştırdığımızda ülkemiz için öneri oluşturabilecek bir husus, ombudsmanlık kurumunun uygulandığı ülkelerde olduğu gibi ülkemizde de silahlı kuvvetler vb. güçler için ayrı bir ombudsman kurulmasıdır. Bir diğer alternatif ise kurumsal bazda bir ayrım yapılmaksızın tüm devlet organlarının üzerinde denetim yetkisine sahip bir ombudsmanlık yapılanmasına gidilmesidir, ancak ülkemiz uygulamasında ayrı bir ombudsman yapılanması oluşturulmadığından ombudsmanın görev alanı konusu Avrupa Birliği İlerleme Raporlarında da eleştirilen bir noktadır (Demirci, 2015, s.50-51).

Görüyoruz ki, ülkemizde ombudsmanın görev alanı farklı ombudsmanlık örnekleriyle kıyaslandığında daha dar kapsamlı tutulmuştur.

Bir diğer önemli husus da kamu denetçiliği kararlarının niteliğine ilişkindir. Ülkemizde ombudsman denetimi sonucunda alınan kararlar "icrai" nitelikte değildir. Bu yönüyle idari denetimin kapsamını karşılamadığı gibi yarg1 kararları gibi "kesin hüküm" niteliği de göstermemektedir. Bu sebeplerle, ülkemizde ombudsman kararları, idare ile vatandaş arasındaki uyuşmazlıkları çözmeye çalışmakla sınırlı kalmaktadır (Demirci, 2015, s. 51). Bununla birlikte, ombudsman kararlarının yargı kararları gibi hukuka uygunluk denetimini kapsamanın yanı sıra hakkaniyet denetimini de kapsadığ ; idarenin eylem ve işlemlerinin yanında kamu görevlilerinin tutum ve davranışlarını da incelemesi, idare ve kamu görevlilerini iyi yönetim ilkelerini uygulamaya yönlendirme açısından önemlidir (Ombudsman.gov.tr/rehber-sikca-sorulansorular39).

$\mathrm{Bu}$ kapsamda ülkemizde ombudsmanlık hakkındaki yasal düzenlemeleri değerlendirdiğimizde, kurumun verebileceği kararlara ilişkin olarak; Kamu Denetçiliği Kurumu Kanunu'nun 20/3. maddesi ve Kamu Denetçiliği Kurumu Kanununun Uygulanmasına İlişkin Usul ve Esaslar Hakkındaki Yönetmeliğin 32. maddesi incelendiğinde: Kurum, yaptığı inceleme ve araştırmalar sonucunda şikâyete konu oluşturan iddianın

- yerinde olduğuna karar vermesi halinde "tavsiye kararı"

- yerinde olmadığına karar verirse "ret kararı"

- bir kısmını yerinde bulmakla birlikte bir kısmını yerinde bulmuyorsa "kısmi tavsiye-kısmi ret kararı"

- tarafları dostane çözüme davet ederek "dostane çözüm” kararı verebilmektedir.

Başvuruların daha kısa sürede sonuçlandırılması açısından "dostane çözüm" yönteminin, 2017 yılı itibariyle kullanılmaya başlamasının, KDK'nın başvuruya ilişkin inceleme-araştırma süreci devam ediyorken bir arabulucu rolü üstlenerek başvuru sahipleri ile idare arasındaki uyuşmazlıkların daha hızlı şekilde çözümünde katkısı olmaktadır (Duran, 2021, s. 13). Dostane çözüm yolunun kullanılması ile kurumun çözüme kavuşturduğu başvuru sayısı da artma eğilimi göstermektedir. Öyle ki, çözüme kavuşturulan başvuru sayısı, 2016 y1lında 4819 adet iken 2017 yılında 14746 adet olmuş ve bu rakam 2019 y1lındaki 21170 adetten 2020 yılında 91100'e ulaşmıştır (KDK Yıllık Raporları). 
Görev, yetki ve sorumlulukları açısından TïHEK'i ele aldığımızda, kurumun, 6701 sayılı Kanun uyarınca, ulusal önleme mekanizması görevi ile insan haklarını korumak ve geliştirmek, ayrımcılık, işkence ve kötü muameleye karşı mücadele etmek ile görevlendirildiği ve bu görevlerin tek bir kurumsal çatı altında toplandığı görülmektedir.

$\mathrm{Bu}$ noktada önemli olan husus, tüm bu yetkilerin tek bir kuruma verilmesinin mi yoksa bu özellikli alanlarda özel yetkili ayrı kurumsal yapıların oluşturulmasının mı daha iyi olduğu noktasındaki tartışmadır. Paris İlkeleri bu konuda biz düzenlemeye yer vermemekle birlikte, Seçmeli Protokol, işkencenin ulusal düzeyde izlenmesi konusunun ayrı bir uzmanlık alanı olarak ayrı bir kuruma verilmesini faydalı görmektedir. Bir kuruma çok sayıda görev vererek ihtiyaç duyulan yetkilerin sakınılıp sakınılmadığ birden çok kurumun insan haklarının korunup geliştirilebilmesi konusunda etkinliği ve verimliliği arttırabileceği şekilde yorum bulmaktadır (Açık, 2011, s.148).

Türkiye İnsan Hakları ve Eşitlik Kurumu'nun görevlerine ilişkin düzenleme 6701 sayılı Kanunun 9. maddesinde yer almaktadır. Yasal düzenleme ile kuruma üç başlık altında görevlendirme yapılmıştır. Buna göre TIHEK'in; "ulusal önleme", "koruma ve geliştirme" mekanizması olmakla birlikte "ayrımcılıkla mücadele" mekanizması olarak da çalışmalar yapmak üzere görevleri:

- Insan haklarına ilişkin ihlal iddialarını resen inceleme, araştırarak karara bağlama ve sonuçlarını izleme, bu kapsamda faaliyet yürüten kamu kurum ve kuruluşları ile birlikte sivil toplum kuruluşlarl, meslek kuruluşları ve üniversiteler ile işbirliği yapma,

- IIskence ve kötü muamele ile mücadele eden ulusal önleme mekanizması olarak BM İşkenceye ve Kötü Muameleye Karşı Ek Ihtiyari Protokol (OPCAT) hükümleri çerçevesinde görev yapma,

- Özgürlüğ̈̈nden mahrum bırakılan ya da koruma altına alınan kişilerin başvurularını inceleme, bu yerlere ziyaret yapabilme ve karara bağladı̆g hususların sonuçlarını takip etme,

- Ayrımcılık yasağı ihlallerine ilişkin olarak başvuru üzerine olduğu gibi resen de inceleme yapabilme, bu konuda mağdurlara yol gösterme,

- Insan haklarının korunup geliştirilmesi ve toplumda eşitlik bilincinin oluşturulması için kamuoyunu bilgilendirme ve eğitim faaliyetlerini yürütme,

- Görev alanı ile ilgili olarak uluslararası alanda insan haklart ve ayrimcilikla mücadele alanındaki gelişmeleri takip ederek alanındaki uluslararası kuruluşlarla ilgili mevzuat dâhilinde işbirliği yapma şeklinde düzenlenmiştir.

Kamu Denetçiliği Kurumu'ndan farklı olarak TİHEK, insan hakları ihlallerine ilişkin olarak resen harekete geçme ve inceleme yapma yetkisine sahiptir. Ayrımcılıkla mücadele konusunda, kuruma, idari yaptırım uygulayabilme yetkisi de tanınmıştır. "Ayrımcılık yasă̆ ihlalinden zarar gördüğü iddiasında bulunan her gerçek ve tüzel kişinin kuruma başvurabilmesi" (md. 17/1) mümkün iken, kuruma "yasama ve yargi yetkilerinin kullanılmasına ilişkin işlemler ile Hakimler ve Savcılar Kurulu kararları ve anayasanın yargı denetimi dışında bıraktığı işlemler" (md. 17/4) için başvuru yapılamamaktadır.

Türkiye İnsan Hakları ve Eşitlik Kurumunun, inceleme ve araştırma görevi çerçevesinde, özgürlüklerinden yoksun bırakılan kişilerin bulundukları yerlere düzenli ziyaretler yapma yetkisine sahip olması önemlidir, ancak bu yetkinin işlerliği için ziyaretlerin habersiz şekilde gerçekleştirilmesi gerekmektedir.

Türkiye İnsan Hakları ve Eşitlik Kurumu'nun ayrımcılık konusundaki görevi kapsamında, istihdam alanındaki cinsiyet temelli ayrımcılık ve mobbing günümüzde sıklıkla gündemde olan ayrımcılık türleridir. Bu tür iddiaların ispatı önemli olmakla birlikte kuruma tanık dinleme ve bilirkişi görevlendirme (md. 20/1) yetkisi de tanınmıştır. 
Beyoğlu/T.C. Kamu Denetçiliği Kurumu ile Türkiye İnsan Hakları ve Eşitlik Kurumu'nun Kurumsal Yapı, İşleyiş ve Etkinlikleri Açısından Bir Karşılaştırma/A Comparison of the Ombudsman and Turkey Human Rights and Equality Institution in Terms of Institutional Structure, Functioning and Efficiency

TİHEK'i, kamu denetçiliğinden farklı kılan bir diğer husus da ihlallerin tespiti halinde, idari yaptırım uygulama noktasında sahip olduğu yetkidir. 6701 sayılı Kanunun 25. maddesine göre TİHEK, ayrımcılık yasağının ihlali halinde;

- "Ihlalin etki ve sonuçlarının ăğrlı̆̆ı, failin ekonomik durumu ve çoklu ayrımcıllğı̆n ağırlaştırıcı etkisini dikkate alarak; kamu kurum ve kuruluşları, kamu kurumu niteliğindeki meslek kuruluşlarl, gerçek kişiler ve özel hukuk tüzel kişileri hakkında 1000 - 15000 TL idari para cezasi" uygulayabilecektir".

- "Bu ceza, bir defaya mahsus olmak üzere uyarı cezasina dönüşürebilecek, ayrımcı fiilinin tekrar halinde ise yüzde elli oranında artirlabilecektir".

- "Ödenen idari para cezast, ayrımcl uygulamaya kusuruyla sebebiyet veren görevliye rücu edilecek"

- "Kurumun taleplerini uyartya rağmen yerine getirmeyenlere ise 500-2000 TL idari para cezasi uygulanacaktır."

Sorumluluk ilkesi, ulusal kurumların üzerine düşen görevleri ile ilgili işlevlerini ne derece yerine getirdiklerini değerlendirmek açısından önemlidir. İnsan hakların korunmasında temel muhatap bireyler ve en nihayette halktır, dolayısıyla ulusal kurumların temel sorumluluğu, halkın insan hakları alanındaki kaygılarını gidermek olduğu kadar bu alanda bir farkındalık yaratmaları da önemlidir. Sorumluluk, kurumsal şeffaflık ve hesap verebilirlik ilkeleri ile bütünleşerek halkın kendi adına ne yapıldığını takip edebilmesi ve çalışmalara vakıf olabilmesi adına önemlidir.

Sorumluluğun bir diğer boyutu ise ulusal insan hakları kurumlarının hangi makama karşı sorumlu olacağı ve bu sorumluluğun hangi yöntemler kullanılarak sağlanacağıdır. Genel olarak kurumlar, parlamentolara, devlet başkanına, başbakana, ya da bakana karşı sorumlu olmakta ve bu sorumluluğunu düzenli aralıklarla değerlendirme raporları sunarak yerine getirmektedir (Aç1k, 2011, s.171).

Sorumluluk açısından Kamu Denetçiliği Kurumu, "yürüttü̈̆̈̈ faaliyetleri ve geliştirdiği önerileri her takvim yılı sonunda bir rapor dâhilinde hazırlayarak, TBMM Dilekçe Komisyonu ile Insan Hakları İnceleme Komisyonu üyelerinden oluşan karma komisyona sunmaktadır (md.22/1). Komisyon ise bu raporu görüşüp kendi görüşlerini de ekleyerek bir rapor hazırlayarak ve genel kurulda görüşülmek üzere TBMM Başkanlı̆̆l'na göndermekte ve bu rapor resmi gazetede yayınlanarak kamuoyu ile paylaşılmaktadır" (md. 22/2). Bu konuda önemli bir nokta da kurumun açıklanmasında fayda gördüğü hususları yıllık rapor dönemini beklemeye gerek duymadan her zaman kamuoyuna duyurabilmesi (md.22/3) olanağına sahip oluşudur. Kaldı ki, kurum, bu alternatif yolu işleterek ihlal/ihlallerde bulunan idare üzerinde kamuoyu baskısı oluşturabilmektedir. Ülkemiz uygulamasında incelediğimiz her iki kurum da düzenlediği raporları, faaliyetleri ve yıllara ait karar örneklerini resmi internet adresleri üzerinden kamuoyu ile paylaşmaktadır.

TİHEK'in sorumlu olduğu resmi makam ise 'Cumhurbaşkanının görevlendireceğ $i$ bakan ile ilişsilidir' şeklinde düzenlenmiştir. Kurum, "Cumhurbaşkanlığına ve TBMM Başbakanlı̆ga sunulmak üzere, yıllık raporlar hazırlamak, gerek görüldü̈̆̈̈nde görev alanına ilişkin özel raporlar hazırlamak" ile görevlidir (md.9). Kurumun kamuoyuna karşı olan sorumluluğu gereği, faaliyetlerine bu faaliyetlere ilişkin raporları ile verdiği kararlara kurumun resmi internet adresi olan https://www.tihek.gov.tr/ üzerinden erişilebilmektedir.

\section{Etkinlik Değerlendirmesi Açısından Kamu Denetçiliği Kurumu ve Türkiye İnsan Hakları ve Eşitlik Kurumu}

İdarenin eylem ve işlemlerine karşı kamuoyunda oluşması istenen güven, temeli ölçeğinde, kamunun etkinliği kavramı ile eşleştirilmekte ve şeffaflık-hesap verebilirlik ilkeleri ile de pekiştirilmektedir (Özer, 2015, s. 34). 
Etkinlik, köken olarak, "başarabilme gücü” anlamında kullanılmakta (Online Etymology Dictionary) ve etkin nitelemesi ile üretim süreci sonunda elde edilen çıktının örgütün, plan, program, amaç ve hedeflerine en iyi derecede yaklaşması ve uyumu açıklanmaktadır (Arslan, 2002, s. 5).

Her iki kurum açısından da faaliyetlerinin ve taleplerin hem nitelik olarak hem de sayısal olarak artması kurumsal etkinliğin sorgulanmasını gerekli kılmaktadır. Bu kapsamda şikâyet başvuruları ve inceleme süreçlerine ilişkin sayısal verilerin yanı sıra kurumların aldı̆̆ 1 kararlara karşı gösterilen uyum kurumsal faaliyetin temel başarı kıstasıdır.

Kamu Denetçiliği Kurumu'na, şikâyet başvurularını kabul etmeye başladığı 29 Nisan 2013 tarihinden bu yana toplam 170744 adet başvuruda bulunulmuştur. Yıllar itibariyle başvuru sayıları incelendiğinde, kamusal alanda, kuruma olan ilginin arttı̆̆ ortadadır. Bu kapsamda, 2013 y1lında 7638 adet olan başvuru sayısı 2014 yılında 5639, 2015 yılında 6055, 2016 yılında 5519, 2017 yılında 17131, 2018 y1lında 17585, 2019 y1lında 20968 ve 2020 yilında ise 90209 adet (KDK Yıllık Faaliyet Raporları) olarak gerçekleşmiştir. Kuruma yapılan başvuru sayılarındaki artış kurumun zaman içerisinde tanınırlı̆̆ının arttığı ve vatandaşların idare ile yaşadığı sorunların çözümünde alternatif bir çözüm yolu olarak görüldüğü şeklinde yorumlanabilir. Bununla birlikte 2020 yılındaki dramatik yükseliş ise dünyayı sarsan Covid-19 salgını sebebiyle tüm dünyada baş gösteren ekonomik sıkıntılara ilişkin olarak ülkemizde de yürütülen kredilendirme politikalarının işleyiş sürecinde idare ile yaşanan uyuşmazlıklardan kaynaklanmaktadır. Bu kapsamda iletilen 70440 adet başvuru finans alanı kaynaklıdır.

Başvuru sayılarındaki artışın yükselme eğilimi göstermesi, kuruma erişim ve tanınırlık açısından önemli gelişmeler olarak nitelense de özellikle bireyler nezdinde tanınır ve kullanılır bir hak arama yolu olması adına kurumların paydaşları ile birlikte daha çok çalışma yürütmesi gerekmektedir.

Başvuru sayılarındaki artış olumlu olarak nitelenmekle birlikte etkinlik adına önemli gösterge, ulusal kurumlar tarafından verilen tavsiye kararlarına idarenin gösterdiği uyumdur. Kamu Denetçiliği Kurumu adına yıllar itibariyle kararlara uyum oranı \%20 oranından \%80 oranına yaklaşmıştır. KDK'nın başvuruları çözüme kavuşturma başarısının özellikle 2017 yılından başlayarak (\%65) arttığ 1,2018 yılında $\% 70,2019$ yılında $\% 75$ ve 2020 y1lında ise $\% 76$ oranına geldiği görülmektedir. Oranlar, yıllar itibariyle artış eğiliminde olmakla birlikte \%80ler düzeyindedir. $\mathrm{Bu}$ oranı arttırabilmek adına kurum tarafından yürütülen çalışmalarda; yıllık raporlar yolu ile şikâyet edilen ilgili idarelere açıkça yer verilmekte ve bu idarelerin kararlara uymama gerekçelerini sözlü olarak TBMM'de düzenlenen yıllık toplantılarda dile getirmeleri talep edilmektedir (ombudsman.gov.tr).

TİHEK açısından ise 2019 yılı faaliyet raporuna göre kuruma yapılan bireysel başvuru sayıs1 1189 olarak gerçekleşmiş; bunların 965 adedi ulusal önleme mekanizması görevine, 70 adedi ayrımcılık yasağına, 124 adedi insan haklarının korunup geliştirilmesine ilişkin ve 30 adedi ise diğer taleplerden oluşmaktadır. Kuruma yapılan başvuru sayısı 2017 yılında 422 adet iken 2018 yılında 1107 adede ulaşmıştır. Başvuru sayıları incelendiğinde kurumlara duyulan ilginin kurumların bilinirliği, erişilebilirliği ve farkındalık arttırıcı çalışmaları ile artmış olduğu gözükmektedir (TİHEK Faaliyet Raporu, 2019). 2020 yılı performans raporunda insan haklarını evrensel değer olarak koruma ve geliştirme adına alınan başvuru ve resen incelemeleri değerlendirme oranı $\% 85^{\prime}$ lik bir oran ile ifade edilmiştir. Aynı yıl, işkence ve kötü muameleyle mücadele görevi kapsamında yapılan ziyaret ve incelemeler neticesinde 10 adet rapor hazırlanmıştır. Ulusal ve uluslararası düzeyde toplantı, konferans, çalıştay vb. çalışmaların sayısı ise 4 adet ile sınırlı kalmıştır. Bilgi ve iletişim teknolojileri, medya ve özellikle sosyal medyanın gücü düşünüldüğünde online platformlardan neden daha fazla faydalanılmadığ 1 sorusu kurumun etkinliğini bu noktada sorgulatır niteliktedir (TIHHEK 2021 Yılı Performans Programi). 


\section{Sonuç ve Öneriler}

İnsan hakları, sadece insan olma onurundan kaynaklanan hak ve özgürlükler bütünü olarak, korunmaları ve geliştirilmeleri için gereken mekanizmaların varlığını gerektirmektedir. $\mathrm{Bu}$ noktada, temel hakların tanınıp güvence altına alınmasının temel muhatabı olan devlet, hukuk devleti ilkesi gereği, bireyleri ihlaller karşısında koruyacak temel mekanizmaları oluşturmak ve idarenin de hukukla bağlı olmasını sağlamakla yükümlüdür.

Devletin, insan hak ve özgürlüklerine ilişkin sorumluluklarını yerine getirmekle yükümlü olan ulusal kurumların, sahip olması gereken temel standartlara ilişkin ilkeler 'Paris Prensipleri' ile düzenlenmiştir.

Paris Prensiplerine göre ulusal kurumlar, insan haklarını koruma kalkanı olarak işlev görmekle birlikte geliştirme, teşvik etme ve farkındalık bilinci oluşturma kapsamında; bağımsız bir şekilde yapılandırılmalı, üye oluşumu çoğulculuk esasına dayandırılmalı, görev, yetki ve sorumlulukları ile üyelerin seçilmesi ve görev teminatları açı bir şekilde yasal düzeyde belirlenmelidir. Kurumların özerkliği ve yeterli mali kaynaklarla donatılmalarının yanında, kolay ve ucuz bir şekilde ulaşılabilir olmaları, sorumlu oldukları makamlara yönelik bildirimlerinde tavsiye ve öneri sunumlarının yanı sıra uluslararası alanda işbirliği yapabilme yetkisi ile donatılmaları gerekmektedir.

Ülkemiz örneğinde ulusal koruma mekanizmalarını oluşturulan Kamu Denetçiliği Kurumu ve Türkiye İnsan Hakları ve Eşitlik Kurumu, Paris Prensiplerine uyumu kapsamında değerlendirildiğinde; kurumların ulusal mevzuatta nerede konumlandırıldıkları ve hangi yetkiler ile donatıldıkları önemlidir. Bu kapsamda Kamu Denetçiliği Kurumu anayasal statüde konumlandırılmışken TİHEK açısından düzenlemenin yasal düzeyde yapıldığı görülmektedir. Kurumların faaliyetlerindeki etkinlikleri açısından normlar hiyerarşisinde ne kadar üst seviyede yapılandırıldıkları önemlidir. Bununla birlikte aldıkları kararların niteliği ve hangi makama karşı sorumlu olarak yapılandırıldıkları da hassas bir noktadır. Verdikleri kararların nitelikleri açısından ne TİHEK ne de T.C. Kamu Denetçiliği Kurumu yargısal kurumlar değildirler. Kamu Denetçiliği Kurumu'nun aldığı kararlarının idareye sunulan bir "tavsiye" niteliğinde olduğu görülmektedir. Kurumun idare üzerinde bir yaptırım yetkisi bulunmamakta ve KDK, iki taraf arasında "arabulucu" rolü üstlenmektedir. Kamu Denetçiliği Kurumu'ndan farklı olarak TIHEK, bağlayıcı kararlar alma yetkisi bakımından idari para cezası uygulanabilme yetkisine sahiptir ve kurum kararları incelendiğinde bu yetkiyi kullandığı da görülmektedir.

Her iki kurumun etkinliği açısından önemli olan bir diğer husus da aldıkları kararlar ve yürüttükleri faaliyetleri ile ilgili olarak hazırlayıp sundukları raporların meclis ve kamuoyunda tartış1labilirliğinin sağlanmasıdır. Meclis düzeyinde bir tartışma her iki kurumun gelişimini ve karalarına uyumu arttıracak nitelikte bir etki yaratacaktır.

Ulusal insan hakları kurumlarının aldıkları kararların niteliği yönünden donatıldıkları yetkilerin yanı sıra ihlalleri gerçekleştirenler üzerinde kamuoyu baskısını ne derece yaratabildiği, etkinlik açısından önemlidir. Eğer ki kurumun kamuoyu ile iletişimi yüksek, yani kurum rapor ve faaliyetleri ile kamuoyuna ne kadar açıksa idare ve ihlalci taraflar üzerinde kamuoyu baskısı oluşturma etkisi de o derece yüksek olacaktır.

Ulusal koruma mekanizmalarının verdiği kararların etkinliğini arttıran bir diğer husus da hak ihlalini gerçekleştiren tarafın verilen kararlara uyumudur. Bu durum ülkede insan hak ve özgürlüklerine duyulan saygının da bir göstergesi olarak; yaptırım uygulanmasa dahi tavsiye niteliğindeki bir karara uyum, ulusal kurumların işlerliğinin asıl teminatını sağlanmış olacaktır.

Ulusal insan hakları kurumlarının etkinliği açısından, denetimlerini nasıl yürüttükleri, yani, bu denetimlerde kendiliğinden harekete geçme ve yerinde inceleme yapma imkânına sahip olup olmadığ1 noktası önemlidir. Kamu Denetçiliği Kurumu'nun, resmen harekete geçme yetkisinin bulunmaması ve şikâyet üzerine incelediği başvurularda da idari başvuru yollarının 
tüketilmesi yönündeki şart hem mağdurları hem de kurumun çalışmasını olumsuz yönde etkilemektedir.

TİHEK ise, özgürlüklerinden mahrum bırakılmış ya da koruma altına tutulanların bulunduğu ceza infaz kurumları, karakolllar vb. yerlerde "yerinde inceleme yapma" yetkisi kapsamında haberli ve habersiz ziyaretler ve incelemeler gerçekleştirebilmektedir. İdari yaptırım uygulayabilme olanağı ile birleşen bu yetki, kurumun, inceleme ve denetimleri ile bireylerin temel hak ve özgürlüklerini koruma ve ihlallere karşı önleyici olma işlevini arttıracaktır.

Kurumlar, erişilebilirlikleri açısından ele alındığında; birey ile idare arasında bir çözüm yolu olarak yargı denetimi, pahalı ve uzun soluklu bir süreç olarak karşımıza çıkmaktadır. Bu açıdan, Kamu Denetçiliği Kurumu ve TIHEK; ucuz, erişiminde alternatif yollar olan ve incelemelerini daha kısa sürede sonuçlandıran kurumlardır.

Ülkemiz pratiği açısından, ihlaller karşısında mağdurların hangi kuruma başvurması gerektiği konusu da ayrı bir düzenlemeyi gerektirmektedir. Paris Prensipleri, ulusal insan hakları kurumlarının özellikle ombudsman olmak üzere insan haklarının korunup geliştirilmesi ile sorumlu tüm organların etkileşim ve iletişim halinde olması gerektiğini düzenlemiştir. Ülkemiz mevzuatı incelendiğinde ise kanun metinlerinde iki kurum arasında açık bir ilişki kurulmadığı görülmektedir. Kamu Denetçiliği Kurumu, kendisine yapılan şikâyet başvuruları üzerine idare ve mağdurlar arasında arabulucu görevini üstlenmektedir. Türkiye İnsan Hakları ve Eşitlik Kurumu ise, insan haklarının korunup geliştirilmesi, ayrımcılık yasağı, işkence ve kötü muamelenin önlenmesi temelinde görevlendirilmiştir. Bununla birlikte, 6701 sayılı Kanun tasarısının gerekçesi incelendiğinde, TïHEK' in görev alanı dışında kalan ihlal iddiaları ile ilgili olarak hangi kuruma başvuru yapılması gerektiği noktasındaki boşluğun Kamu Denetçiliği Kurumu tarafindan doldurulması gerektiği şeklinde bir yorumlamaya yer verilmektedir. $\mathrm{Bu}$ iletişimin pratiğe yansıması aşamasında ülkemiz açısından üzerinde durulması gereken husus, bu iki kurum arasında bir iş bölümü olup olmadığ 1 ya da nasıl olması gerektiğidir. Bu amaçları incelediğimizde, ihlaller karşısında her iki kurum arasında başvuruların yönlendirilmesi yönünde yapılacak bir düzenlemenin mağdurlar lehine erişimi kolaylaştırıcı olacağı ortadadır.

Ülkemiz açısından ombudsman türleri ve görevleri değerlendirildiğinde; değişen ihtiyaçlar ve talep çeşitliliği de dikkate alındığında, genel amaçlı-görevli bir ombudsmanlık yapılanması ile birlikte insan haklarının korunup geliştirilmesi, işkence, kötü muamele ve ayrımcılık hususlarında TİHEK'in görev alanı saklı kalmak kaydıyla dünya örneklerinde olduğu gibi, belirli kesimlerin şikayetleri ile ilgilenen özel amaçlı ombudsman yapılanmasının gerekliliği de tartışılabilir. KDK 2020 yılı faaliyet raporunda şikâyet başvurularının sektörel bazda idarelere göre dağılımı başlıklı sunumda, dikkat çekici şekilde \%76.18 oranında ifade edilen şikâyetlerin banka ve finans kuruluşları ile ilgili olduğu göze çarpmaktadır (KDK 2020 Yılı Yıllık Raporu, s. 71-72). Bunun gibi, özellikle vatandaşa en yakın idareler olan mahalli idarelerce yürütülen hizmetlere yönelik şikayet başvurularının da son yıllarda Kamu Denetçiliği Kurumu'na iletilen başvuru sayılarında ilk sıralarda yer alıyor oluşu, yerel hizmetlerin iyileştirilmesi alanına yönelik olarak oluşturulabilecek özel görevli ombudsmanları gerekli kılmaktadır. Bu husus, Kamu Denetçiliği Kurumu'nun iş yükünü azaltacak ve özel görevli ombudsmanın uzmanlığından faydalanılarak şikâyetler daha hızlı ve etkin şekilde sonuçlandırılabilecektir.

Güncel konularda, yazılı-görsel basın ve sosyal medya ile ilişkilerin gelişimi ile gelen hızlı iletişim kolaylığından faydalanılarak özellikle kadın ve çocuk hakları gibi alanlarda zincirleme olarak katılım, eğitim, şiddet, sağlık gibi bir dizi hak ihlalinin doğma potansiyeli düşünülerek alternatif iletişim kanalları etkin işletilmelidir.

Yıllık raporlar yolu ile bilgilendirme konusunda, hazırlama ve kamuoyu ile paylaşma zorunluluğu her iki kurumun da görev alanında bulunmaktadır. Her iki kurum da yıllık rapor ve gerek gördüğünde özel raporlar hazırlamak ile görevlendirilmiştir. Raporları işlevsel kılan husus 
ise kamuoyu ile paylaşılmasından da öte bu raporların tartışılabilir olmasını sağlamaktır. Özellikle, raporların Türkiye Büyük Millet Meclisi seviyesinde tartışılması kamuoyunda oluşturulacak moral değer ve hassasiyet açısından önem arz etmektedir.

Son olarak, insan haklarının korunup geliştirilmesi gibi kritik bir alanda faaliyet gösteren kurumların pratikleri bakımından etkinliği ve şeffaflık ilkesini ne derece işlettikleri de önemlidir. Bu kapsamda değerlendirdiğimizde TİHEK ve Kamu Denetçiliği Kurumu'nun faaliyet, rapor ve kararlarına ulaşılabilirlik önemlidir. Kamu Denetçiliği Kurumu adına Başdenetçi Şeref Malkoç, idarenin kararlara uyumuna ilişkin verileri kaynak göstererek tavsiye kararlarına uyum konusunda Avrupa örneklerine yaklaşıldığını, 2013 yılında KDK kararlarına idarenin uyum oranı yüzde 20 iken 2020 yılında bu oranın yüzde 80'lere yükseldiğini belirtmiştir (KDK'dan Haberler, 2020).

\section{Kaynakça}

Açık, C. (2011). Ulusal insan hakları kurumları ve Türkiye örneğine eleştirel bir yaklaşım (Yayımlanmamış yüksek lisans tezi). Ankara Üniversitesi Sosyal Bilimler Enstitüsü, Ankara.

Aktel, M. Kerman, U. Altan, Y. Lamba, M. ve Burhan, O. (2013). Türkiye için yeni bir denetim modeli: kamu denetçiliği. Mehmet Akif Ersoy Üniversitesi Sosyal Bilimler Enstitüsü Dergisi, 5(9), 21-37.

Arslan, A. (2002). Kamu harcamalarında verimlilik, etkinlik ve denetim, Maliye Dergisi, (141), $76-83$

Büyükavc1, M. (2008). Ombudsmanlık kurumu. Ankara Barosu Dergisi, 66 (4), 10-13.

Çağlar, S. (2012). Engellilerin erişebilirlik hakkı ve Türkiye'de erişebilirlikleri. Ankara Üniversitesi Hukuk Fakültesi Dergisi, 61(2), 541-598.

Çağlar, S. (2017). Türkiye'de ombudsmanlık kurumunun etkinliğini azaltan hukuki nedenler ve çözümleri. Ö. Kalkan Küçüksolak (Ed), İstanbul: IJOPEC Publication, 231-245.

Demirci, K. (2015). Alternatif uyuşmazlık çözüm yollarından biri olarak Kamu Denetçiliği Kurumu (Yayımlanmamış yüksek lisans tezi). Turgut Özal Üniversitesi Sosyal Bilimler Enstitüsü, Ankara.

Didinmez, M. A. (2020). Ulusal insan hakları kurumları küresel ağına akreditasyon çerçevesinde Türkiye Insan Hakları ve Eşitlik Kurumu incelemesi (Yayımlanmamış yüksek lisans tezi). Ankara Üniversitesi Sosyal Bilimler Enstitüsü, Ankara.

Donnelly, J. (1989). Teoride ve uygulamada insan hakları, (M.Erdoğan ve L.Korkut Çev.), Ankara: Yetkin Yayınları.

Duman, E. (2017). Ayrımcılık yasağ ve Türkiye insan hakları ve eşitlik kurumu raporu.

Duran, H. (2021). Türkiye'de idari denetim ve kamu denetçiliği kurumu, Seta Analiz, 1-19.

Efe, H., Demirci, M. (2013). Ombudsmanlık kavramı ve Türkiye'de kamu denetçiliği kurumu'ndan beklentiler, Saylştay Dergisi, 90, 49-73.

Fendoğlu, H. T. (2010). Kamu denetçiliği (ombudsmanlık). SDE Analiz. http://hasantahsinfendoglu.com/dokumanlar/insan_haklari/KAMU_DENETCILIGI_OMBD USMANLI K_.pdf

Fendoğlu, H. T. (2013). Kamu denetçiliği (ombudsman) ve Anayasa Mahkemesi'ne bireysel başvuru hakk1. Ankara Barosu Dergisi, 4, 21-49.

Gözler, K. (2017). Klsa İdare Hukuku. Bursa: Ekin Yayınevi. 
Kahraman, M. (2011). Hukuk devletine katkıları bakımından kamu denetçiliği. Mustafa Kemal Üniversitesi Sosyal Bilimler Enstitüsü Dergisi, 8(16), 355-373.

Köker, L. (2006). Seçim sistemleri ve siyasi çoğulculuk: demokratik meşruluk açısından bir değerlendirme. Anayasa Yargısı 23, 199-210.

Odyakmaz, Z. Keskin, B. ve Deniz, Y. (2016). 6701 sayılı Türkiye İnsan Hakları ve Eşitlik Kurumu Kanunu üzerine bir değerlendirme-I. Uyuşmazlık Mahkemesi Dergisi, (7), 721-761.

Oytan, M. (1975). Ombudsman eli ile idarenin denetimi konusunda kıyaslamalı bir inceleme, Danıştay Dergisi, (18-19), 193-214.

Özdemir, B. (2014). Kamu denetçiliği kurumunun işlevi ve yapısı (Yayımlanmış yüksek lisans tezi). Ankara Üniversitesi Sosyal Bilimler Enstitüsü, Ankara.

Özer, M. A. (2015). Türkiye'de kamu yönetiminin denetiminde yeni arayışlar: kamu denetçiliği kurumu örneği, Saylştay Dergisi, (98), 19-40.

Pickl, V. (1986). Ombudsman ve Yönetimde Reform, Amme İdaresi Dergisi, 19(4), 37-46.

Sobac1, M. Z., Köseoğlu, Ö. (2016). Ombudsman ve sosyal medya: Kamu Denetçiliği Kurumu'nun twitter kullanımına ilişkin ampirik bir analiz, Ankara Üniversitesi SBF Dergisi, 71(1), 103-124.

Şengül, R. (2007). Türkiye'de kamu yönetiminin etkin denetlenmesinde yeni bir kurum: kamu denetçiliği kurumu, Kocaeli Üniversitesi Sosyal Bilimler Enstitüsü Dergisi, 14, 126-145.

URL-1: 6328 sayılı Kamu Denetçiliği Kurumu Kanunu, https://www.ombudsman.gov.tr/contents/files/6328\%2C.pdf (Erişim tarihi: 01.03.2018).

URL-2: 6701 sayılı Türkiye İnsan Hakları ve Eşitlik Kurumu Kanunu, http://www.mevzuat.gov.tr/MevzuatMetin/1.5.6701.pdf (Erişim tarihi: 01.03.2018).

URL-3: İnsan Hakları ve Eşitlik Uzmanlığı Yönetmeliği, http://www.resmigazete.gov.tr/eskiler/2017/11/20171111-1.htm (Erişim tarihi: 01.03.2018).

URL-4: İnsan Hakları Koruma Mekanizmaları: Türkiye İnsan Hakları Rejiminin Anatomisi, www.liberalforum.eu/en/publications.html (Erişim tarihi: 28.09.2018).

URL-5: Kamu Denetçiliği Kurumu Kanunun Uygulanmasına İlişkin Usul ve Esaslar Hakkında Yönetmelik, http://www.mevzuat.gov.tr/Metin.Aspx?MevzuatKod=7.5.17239\&MevzuatIliski=0\&source $\mathrm{XmlSearch}=\mathrm{kamu} \% 20 \mathrm{denet} \% \mathrm{C} 3 \% \mathrm{~A} 7 \mathrm{ili} \% \mathrm{C} 4 \% 9 \mathrm{Fi}$ (Erişim tarihi: 13.05.2020).

URL-6: KDK Karar1, Şikayet No: 03.2013/310, Karar no:2013/90, http://www.ombudsman.gov.tr/ (Erişim tarihi: 20.05.2018).

URL-7: Paris Prensipleri, https://www.ombudsman.gov.tr/contents/files/717ParisPrensipleri.pdf (Erişim tarihi: 01.03.2018).

URL-8: Say1 : 86171061-101.07.04-E.4153 , Başvuru No : 2017/2171, Karar Tarihi 28.04.2017, http://www.ombudsman.gov.tr/ (Erişim tarihi: 20.05.2018).

URL-9: T.C. Anayasas1, https://www.tbmm.gov.tr/anayasa/anayasa82.htm (Erişim tarihi:01.03.2018).

URL-10: Türkiye İnsan Hakları ve Eşitlik Kurumu Kanununun Uygulanmasına İlişkin Usul ve Esaslar Hakkında Yönetmelik, http://www.resmigazete.gov.tr/eskiler/2017/11/201711242.htm (Erişim tarihi: 10.07.2019)

URL-11: https://www.tbmm.gov.tr/komisyon/dilekce/index.htm (Erişim tarihi: 09.01.2021). 
URL-12: https://www.ombudsman.gov.tr/contents/files/pdf/kdk-2017-2021-stratejik-plan.pdf (Erişim tarihi: 09.01.2021).

URL-13: https://www.ombudsman.gov.tr/kdknin-verdigi-tavsiye-kararlarina-uymayan-idarelertbmmye-cagirildi/index.html (Erişim tarihi: 10.11.2020).

URL-14: https://www.ombudsman.gov.tr/rehber-sikca-sorulan-sorular/index.html (Erişim tarihi: 10.10.2019).

URL-15: https://www.tihek.gov.tr/milliyet-22-03-2019 (Erişim tarihi: 20.05.2019).

URL-16: https://www.tihek.gov.tr/upload/file_editor/2020/02/1582925332.pdf (Erişim tarihi: 10.11.2020).

URL-17: https://www.oxfordlearnersdictionaries.com/definition/english/ombudsman, (Erişim tarihi: 11.11.2020).

URL-18: https://kdkcocuk.gov.tr/anasayfa/hakkimizda/index.html?theme=the-box， (Erişim tarihi: 04.01.2021).

URL-19: https://www.ombudsman.gov.tr/basin-toplantisi.html, (Erişim tarihi: 05.01.2021).

URL-20: http://insanhaklarimerkezi.bilgi.edu.tr/tr/content/36-turkiye-insan-haklar-ve-esitlikkurumu/, (Erişim tarihi: 10.01.2021).

URL-21: https://www.haberturk.com/yerel-haberler/haber/13379057-tihek-heyeti-trabzonda, (Erişim tarihi: 05.01.2021).

URL-22: https://www.tihek.gov.tr/upload/file_editor/2020/07/1594385979.pdf (Erişim tarihi: 30.06.2021).

URL-23: Efficiency, https://www.etymonline.com/word/efficiency (Erişim tarihi: 30.06.2021).

URL-24: Kamu Denetçiliği Kurumu Yıllık İdari Faaliyet Raporları, https://www.ombudsman.gov.tr/Publishing/IdareFaaliyetRaporlari.html (Erişim tarihi: 02.07.2021).

URL-25: TIHEK 2021 Y1l1 Performans $\quad$ Program1, https://www.tihek.gov.tr/upload/file_editor/2020/10/1603466520.pdf (Erişim tarihi:05.07.2021).

URL-26: Uluslararası İlişkiler, https://www.tihek.gov.tr/bm-ve-ulusal-insan-haklari-kurumlari (Erişim tarihi: 05.07.2021).

\section{ETIKK ve BİLIMSEL İLKELER SORUMLULUK BEYANI}

$\mathrm{Bu}$ çalışmanın tüm hazırlanma süreçlerinde etik kurallara ve bilimsel atıf gösterme ilkelerine riayet edildiğini yazar beyan eder. Aksi bir durumun tespiti halinde Afyon Kocatepe Üniversitesi Sosyal Bilimler Dergisi'nin hiçbir sorumluluğu olmayıp, tüm sorumluluk makale yazarına aittir. 